Article

\title{
Ventilation Systems and Their Impact on Nanoparticle Concentrations in Office Buildings
}

\author{
Henrik Olstrup ${ }^{1}$, Annika Hagenbjörk ${ }^{2}$ and Hans Orru 1,2,* \\ 1 Institute of Family Medicine and Public Health, Faculty of Medicine, University of Tartu, Ravila 19, \\ 50411 Tartu, Estonia; henrik.olstrup@ownit.nu \\ 2 Section of Sustainable Health, Department of Public Health and Clinical Medicine, Faculty of Medicine, \\ Umeå University, 90187 Umeå, Sweden; annika.hagenbjork@umu.se \\ * Correspondence: hans.orru@umu.se; Tel.: +372-737-4203
}

Citation: Olstrup, H.; Hagenbjörk, A.; Orru, H. Ventilation Systems and Their Impact on Nanoparticle Concentrations in Office Buildings. Appl. Sci. 2021, 11, 8930. https:// doi.org/10.3390/app11198930

Academic Editor: José A. Orosa

Received: 20 August 2021

Accepted: 21 September 2021

Published: 25 September 2021

Publisher's Note: MDPI stays neutral with regard to jurisdictional claims in published maps and institutional affiliations.

Copyright: (c) 2021 by the authors. Licensee MDPI, Basel, Switzerland. This article is an open access article distributed under the terms and conditions of the Creative Commons Attribution (CC BY) license (https:/ / creativecommons.org/licenses/by/ $4.0 /)$.
Featured Application: The current study provides information on nanoparticle concentrations in offices and discusses how to reduce them, e.g., using higher class filters in ventilation systems.

Abstract: Nanoparticles (NPs) can infiltrate indoor environments and have a large impact on human health when inhaled. Thus, indoor air quality is highly dependent on the outdoor air and on the filters used in the ventilation systems. In the NanoOffice study, the concentrations and the size distribution of NPs were measured with a five-minute time resolution in twelve office buildings in Umeå. Measurements were taken with an SMPS 3938 during a one-week period in the heating and nonheating seasons. Large differences in ventilation between buildings appeared, despite the fact that similar MVHR ventilation systems were used, and most of them were equipped with F7 filters. The NP concentrations and the simultaneous ventilation flows were measured in buildings with a variable and a more constant ventilation flow. In some cases, an increase in NP concentration could be seen after ventilation turn-on or after an increase in the ventilation flow. There was also one case where the NP concentrations increased in connection with the ventilation being switched off or reducing its flow. However, variable NP concentrations were also shown in buildings with a fairly constant ventilation flow, which was prominent for the two buildings located closest to busy streets. The correlation coefficients between the ventilation flow and particles in different size classes were in general smallest for particles in the smallest size classes, indicating higher filtration efficiency.

Keywords: air quality; indoor air; nanoparticles; health; ventilation; filter efficiency

\section{Introduction}

Nanoparticles are important to address due to their very small size and high penetration rate [1]. A nanoparticle is defined as a submicroscopic particle that measures less than 100 nanometers ( $\mathrm{nm}$ ) on at least one of its dimensions [2]. However, the term is also

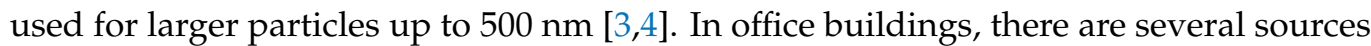
of nanoparticles originating both indoors and outdoors. Indoor sources of nanoparticles include electrical appliances [5], the release from several types of construction materials [6], and emissions from laser printers [7]. Outdoor air is also an important source of nanoparticles, where the particles enter the buildings through infiltration or ventilation [8].

Healthy indoor air quality is crucial in terms of employees' health [9]. The main purpose of the ventilation systems used in buildings is to supply healthy air, diluting pollutants originating inside the building, and removing the pollutants from the ambient air. There are three factors that are especially important to consider for ventilation in buildings: (1) The amount of outdoor air that moves into the airspace of the building, and the quality of the outdoor air taken into the building; (2) The airflow direction inside a building, which should be from clean zones to polluted zones; and (3) The external air should be distributed to all parts of the building in an efficient manner, and the air 
pollutants generated in each part of the building should also be removed in an efficient manner [10].

There are three methods that are used in order to ventilate a building: natural ventilation (NV), mechanical ventilation (MV), and hybrid ventilation (HV). NV is driven by thermal forces that arise as a result of differences in the density of the indoor and outdoor air. The outdoor air flows in through purpose-built openings that include windows, doors, solar chimneys, wind towers, and trickle ventilators. The efficiency of NV largely depends on the temperature difference between the indoor and outdoor air. MV uses fans in order to create pressure, which in turn creates air exchange within a building. MV can be based on either an overpressure system, a negative pressure system, or a combination of these. An overpressure system uses fans at the air intake where the air is supplied to the building. A negative pressure system uses fans that suck the air out of the building. $\mathrm{HV}$ is a combination of natural and mechanical ventilation. HV relies on natural driving forces in order to maintain an air exchange within a building, but it is equipped with fans that can be activated when the natural driving forces become insufficient [10].

The effects of ventilation methods on particle concentrations indoors have been addressed in a number of studies. In a study from Sydney, Australia, air pollutants were measured indoors during one year in eleven occupational buildings with ventilation systems representing NV, MV and HV. In general, the buildings equipped with an MV system showed the lowest average concentrations of both TSP (total suspended particles), particulate matter $\left(\mathrm{PM}_{10}\right)$, and fine particles $\left(\mathrm{PM}_{2.5}\right)$ [11]. In another study in Seoul, South Korea, where the influence of different ventilation systems on indoor particle concentrations was analyzed in 15 single-family apartments, it appeared that MV reduced the exposure to outdoor particles more than NV. When the apartments were mechanically ventilated, the daily average indoor particle concentration decreased to $50 \%$ below the outdoor level for submicrometer particles $(<1 \mu \mathrm{m})$ and $25 \%$ below the outdoor level for fine particles [12].

In general, mechanical ventilation equipped with filters reduces the particle concentrations indoors, but the magnitude of this effect depends on the efficiency, location, and the number of filters applied [13,14]. Karjalainen et al. [15] found that the concentration of indoor nanoparticles originating outdoors was largely determined by the filtration efficiency of the filters used in the ventilation system. The filters are classified according to their ability to capture particles at different sizes, defined as filtration efficiency. The abbreviations $\mathrm{M}$ and $\mathrm{F}$ stand for medium and fine where the filters classified as fine have a higher degree of separation in comparison with the filters classified as medium. The filtration efficiency for different filters at different particles sizes is presented in Table 1.

Table 1. The degree of separation in percent for different filters at different particle sizes [16].

\begin{tabular}{ccccc}
\hline $\begin{array}{c}\text { Filter Class According to } \\
\text { SS EN 779 1 }\end{array}$ & $\mathbf{4 0 0} \mathbf{~ n m ~}$ & MPPS $^{\mathbf{2}}$ & $\mathbf{5 0} \mathbf{~ n m ~}$ & $\mathbf{2 0} \mathbf{n m}$ \\
\hline M5 & $4 \%$ & $2 \%$ & $17 \%$ & $30 \%$ \\
M6 & $20 \%$ & $14 \%$ & $35 \%$ & $63 \%$ \\
F7 & $58 \%$ & $46 \%$ & $62 \%$ & $83 \%$ \\
F8 & $70 \%$ & $55 \%$ & $69 \%$ & $90 \%$ \\
F9 & $81 \%$ & $60 \%$ & $77 \%$ & $94 \%$ \\
\hline
\end{tabular}

${ }^{1}$ SS EN 779 = Swedish standard for testing and classification of ventilation filters. ${ }^{2}$ MPPS = "Most Penetrating Particle Size". It refers to the particle size that is most difficult to filter. This size varies depending on the structure of the filter and its performance, the air velocity through the material, as well as the properties of the particles.

Moreover, different ventilation conditions (closed windows, windows opened for short periods, and windows tilted open all day long) might influence indoor air quality. Cyrys et al. [17] analyzed a hospital building in Erfurt, Germany, and found that the lowest indoor/outdoor $(\mathrm{I} / \mathrm{O})$ ratios for all pollutants were found with closed windows. The smallest I/O ratio for particle number concentration (PNC) was found with closed windows with the value of 0.33 . In Daqing, China, the lower infiltration factors for fine particles $\left(\mathrm{PM}_{2.5}\right)$ in offices and urban residential were mainly caused by closing the windows and using air 
conditioning as well as due to a greater air tightness in high buildings [18]. Miller et al. [19] studied the correlations between particle concentrations measured indoors and outdoors in mechanically ventilated buildings in Colorado, USA. The correlations between indoor and outdoor concentrations were higher for UFP (55-100 nm) in comparison with fine particles $(0.1-0.7 \mu \mathrm{m})$, especially when the heating, ventilating, and airconditioning (HVAC) system was running. This study also showed that the $\mathrm{I} / \mathrm{O}$ ratios of particles in the different size fractions were weakly but positively correlated with the amount of ventilation provided to the indoor environment.

The I/O relationships for particles in different size modes (nucleation mode, Aitken mode, and accumulation mode), and at different ventilation conditions, have been analyzed in a few studies.

Particle size distributions indoors and outdoors were measured in a building in Helsinki downtown during 1999. The I/O ratio for nucleation mode particles $(8-25 \mathrm{~nm})$ was mostly around 0.1 . For particles in the Aitken mode $(25-90 \mathrm{~nm})$, the I/O ratio was mostly between 0.1 and 0.2 . For particles in the accumulation mode $(90-500 \mathrm{~nm})$, the $\mathrm{I} / \mathrm{O}$ ratio was mostly around 0.3 . When the ventilation flow was switched on, the $\mathrm{I} / \mathrm{O}$ ratio for particles in accumulation mode increased. However, during nighttime, when the ventilation flow was very low, the I/O ratio for particles in nucleation mode increased [20]. In another study performed in Helsinki, the number concentrations of fine particles were measured indoors and outdoors in an office located in the basement of a building in Helsinki. The measurements took place in the summer of 2000. Particles in the size range of 7-600 nm were measured, and there was a temporal correlation between the particle number concentrations measured indoors and outdoors. The mechanical ventilation system was the main transport route of outdoors particles into the building. The mean penetration factor was 0.41 for nucleation mode particles $(7-25 \mathrm{~nm}), 0.74$ for Aitken mode particles (25-100 nm), and 0.87 for particles in accumulation mode (100-600 nm) [21].

In a study performed in California, indoor and outdoor relationships for particles in the size range of 6-220 nm were measured in four apartments within $60 \mathrm{~m}$ from the center of the 405 Freeway in Los Angeles. Indoor and outdoor concentrations were measured simultaneously under different ventilation conditions without the presence of any indoor sources that generated particles. Under different air exchange rates, the $\mathrm{I} / \mathrm{O}$ ratios were highest (0.6-0.9) for particles in the size range of 70-100 nm, while the lowest I/O ratios $(0.1-0.4)$ were found for particles in the size range of 10-20 $\mathrm{nm}$ [22]. In a study performed in Rochester, New York, USA, the concentrations of particles in the size range of 10-500 nm were measured inside and outside of a commercial building during the period of 2005-2009. The ventilation was based on an HVAC system. In general, the I/O ratio increased with particle size [23].

In general, the measurements of nanoparticles in buildings are scarce, and information on the role of ventilation systems on particle concentration is limited. The current analysis is a further development of the NanoOffice study focusing on nanoparticle concentrations in office buildings in the city of Umeå in the northern part of Sweden [24]. In this analysis, the main focus is on the ventilation systems used in the studied office buildings and how these affect the nanoparticle concentrations measured indoors.

Automatic means that the ventilation is controlled by sensors for carbon dioxide, humidity, air temperature, and/or presence in the residence zone, in order to maintain the size of the air flow after the current load.

\section{Materials and Methods}

Nanoparticle concentrations were measured in twelve office buildings in the city of Umeå in northern Sweden during the year 2017 and 2018. The locations of the office buildings are presented in Figure 1. The concentration and size distribution of nanoparticles were measured with 5-min intervals during two one-week periods representing both the heating and nonheating seasons. The measurements were performed in office rooms with an area of between $\sim 10$ and $\sim 20 \mathrm{~m}^{2}$, and no people entered these rooms during the 
measurements. Windows and doors were closed during the measurements, and there were no printers located in these rooms. The twelve office buildings were selected to include newer, retrofitted, and older buildings with various ventilation systems and energy efficiency. The office buildings were also chosen according to different distances from busy streets as the main sources of combustion-formed nanoparticles (CFNPs). The nanoparticles were measured using SMPS 3938 (SMPS = Scanning Mobility Particle Sizer Spectrometer, TSI Inc., Shoreview, MN, USA). This technique is described more detailed in the earlier analysis by Orru et al. (2021) [24], and it is shown in Figure 2. The nanoparticles that were measured as particle number concentration (PNC) in this study consist of fractions in different size classes in the range of $10 \mathrm{~nm}$ up to $461 \mathrm{~nm}$.

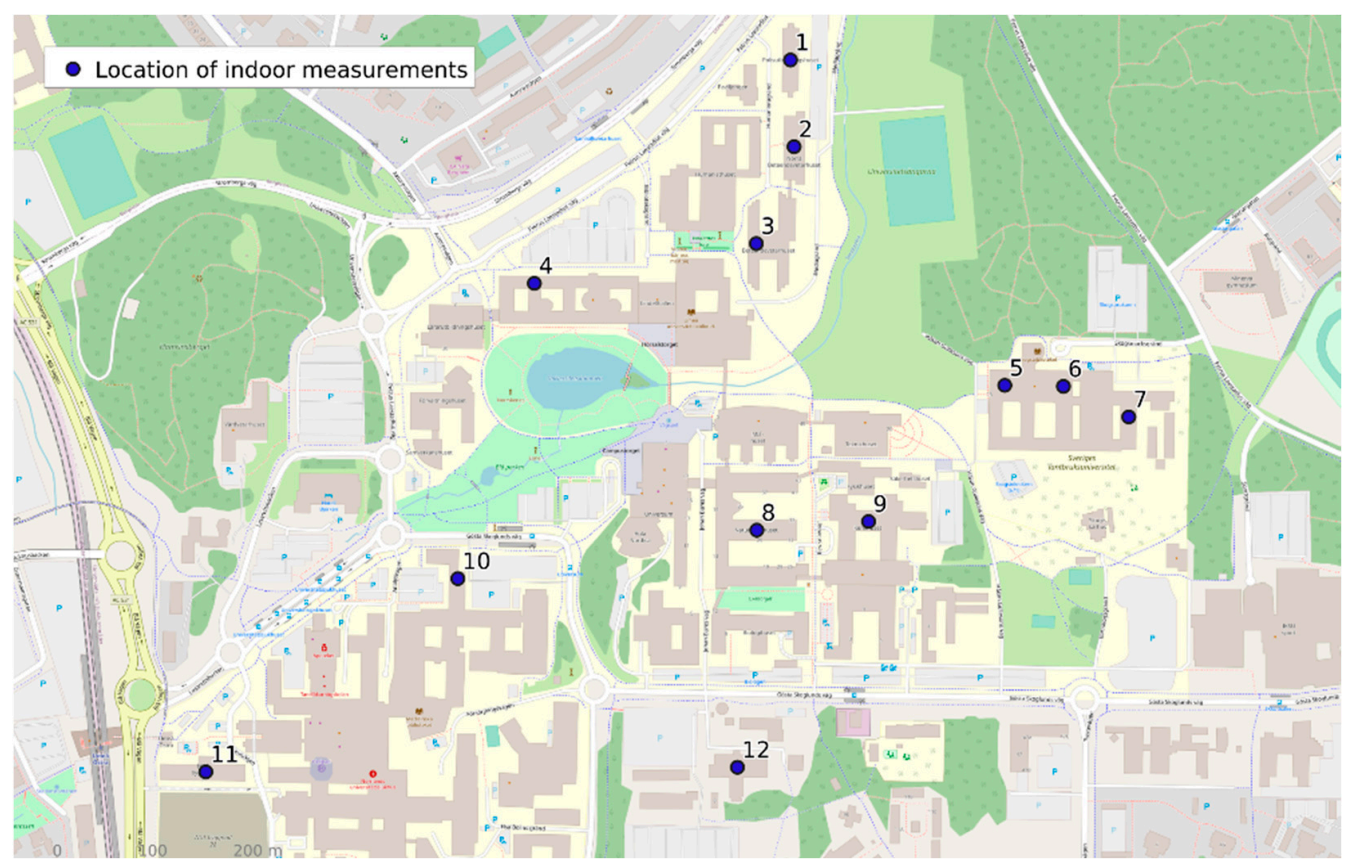

Figure 1. The study area with the location of Buildings 1-12, where indoor measurements were carried out. Basemap: (C) OpenStreetMap contributors.

The ventilation systems in the twelve buildings were all based on mechanical ventilation with heat recovery (MVHR). It was a fan-controlled supply and exhaust air system with heat recovery. Air ducts were used to supply air and exhaust air to control the flow of air so that air pollutants were eliminated as efficiently as possible. The MVHR system was also equipped with a heat exchanger where the heat energy in the heated indoor air was used in order to heat the cold incoming air.

The majority of the ventilation systems of the studied buildings were equipped with filters of class F7 (despite Building 10 with filter of class M6). For Building 1, no detailed information was available (security classified), but as it was a new building, it has filters $\geq$ F7. More detailed information of buildings and ventilation systems were presented in the earlier analysis by Orru et al. (2021) [24].

In parallel with nanoparticle measurements, the air velocity $(\mathrm{m} / \mathrm{s})$ was identified as 5-min average. The measurements were conducted with a multifunctional environmental meter AMI310 (KIMO Instruments. Sauermann Industrie SAS, Montpon-Ménestérol, France) equipped with a $\varnothing 100 \mathrm{~mm}$ telescopic vane probe and airflow cone (Figure 2). Ventilation flow $\left(\mathrm{m}^{3} / \mathrm{h}\right)$ was calculated by multiplying the air velocity by the cross-sectional area of the cone:

$$
\mathrm{q}_{\mathrm{m}}=\mathrm{v}_{\mathrm{m}} \times\left[\pi \times\left(\mathrm{d}_{\mathrm{m}} / 2\right)^{2}\right] \times 3600
$$

where the included variables are defined as follows:

$\mathrm{q}_{\mathrm{m}}=$ ventilation flow $\left(\mathrm{m}^{3} / \mathrm{h}\right)$ 


$$
\begin{aligned}
& v_{\mathrm{m}}=\text { air velocity }(\mathrm{m} / \mathrm{s}) \\
& \mathrm{d}_{\mathrm{m}}=\operatorname{diameter} \text { of duct }(\mathrm{m}) \\
& \pi=\mathrm{pi}
\end{aligned}
$$

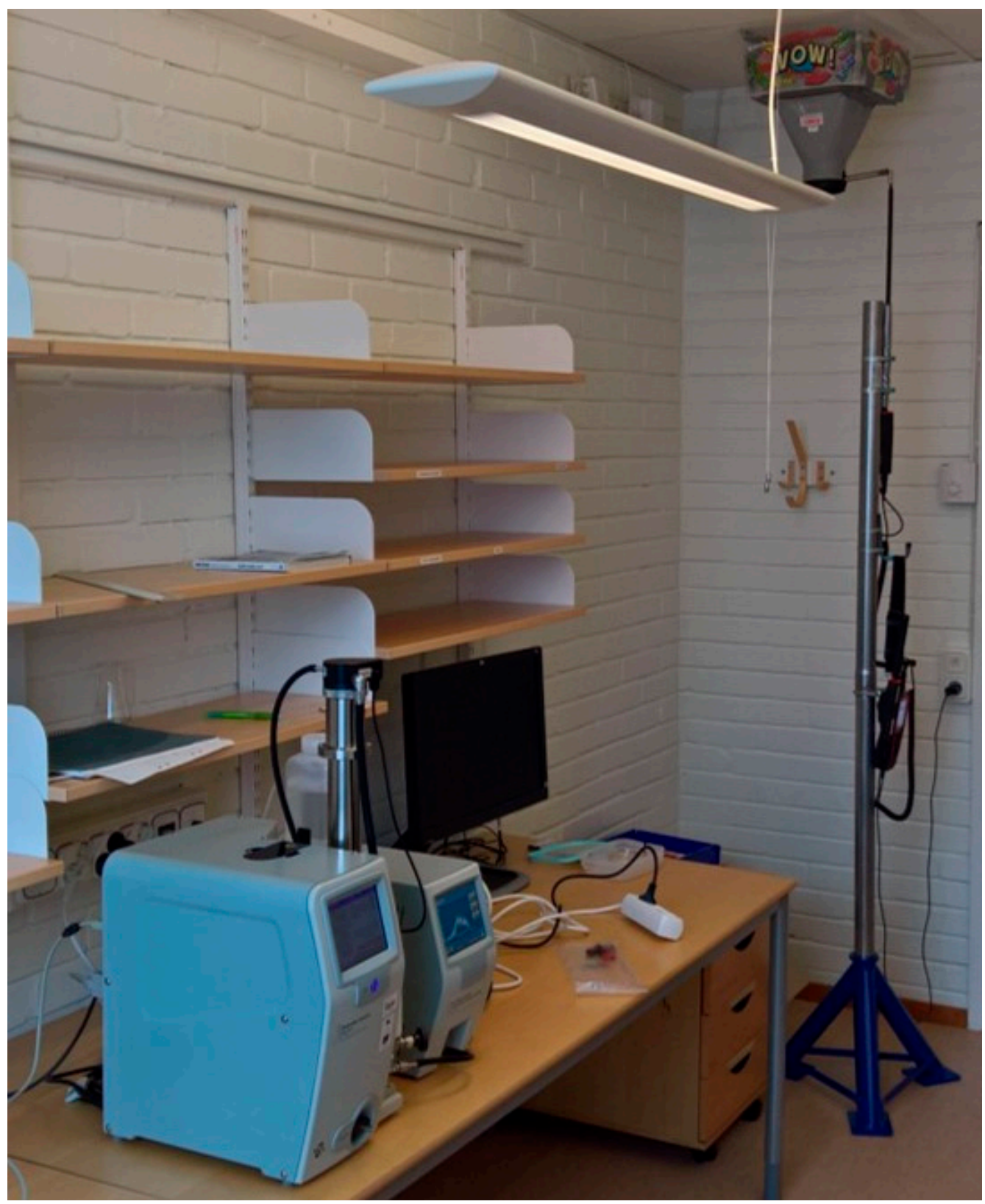

Figure 2. Measurement of nanoparticles indoors with SMPS 3938 (left) and ventilation flow with AMI310 (right).

In terms of nanoparticle (hereinafter abbreviated NP) concentrations and the importance of ventilation, there are a number of factors that determine the concentrations of indoor pollutants including NPs. The main factors can be mathematically illustrated by the following differential equation (Atkinson et al., 2009) [10]:

$$
\mathrm{V} \frac{d c}{d t}=\mathrm{q}\left(\mathrm{C}_{0}-\mathrm{C}\right)+\mathrm{V}_{\mathrm{pol}}
$$

where the included variables are defined as follows:

$\mathrm{V}=$ volume of space 
$\mathrm{c}=$ concentration $\left(\right.$ particles per $\left.\mathrm{cm}^{3}\right)$

$\mathrm{q}=$ ventilation rate $\left(\mathrm{cm}^{3} / \mathrm{s}\right)$

$\mathrm{C}_{0}=$ supply air concentration (particles per $\mathrm{cm}^{3}$ )

$\mathrm{dc}=$ change in concentration

$\mathrm{dt}=$ change in time

$\mathrm{V}_{\text {pol }}=$ indoor pollutant generation in the room (particles per second)

In this study, the ventilation flow and the ability of the filters to absorb particles at different size classes were the two main factors on which the results are based. The correlations between the airflow in the ventilation systems and the simultaneously measured NP concentrations were calculated. The correlations between the airflow and the NP concentrations were also calculated for the different size fractions of the measured NPs, along with the ability of filters to absorb particles at different size classes to control the flow of air so that air pollution is eliminated as efficiently as possible.

\section{Results}

\subsection{Concentrations of Nanoparticles}

The concentrations of NPs varied quite largely between the different buildings (Figure 3). The highest concentration was found in a newly completed building, especially during the heating season, just a few weeks after opening. The maximum values reached around 30,000 particles per $\mathrm{cm}^{3}$. High concentrations were also found in the two buildings closest to a busy street; however, this trend did not appear in the nonheating season (Table 2). The lowest concentrations were found in a building near a park. In some of the buildings, the concentrations were higher during the heating season, whereas in other buildings, they were higher during the nonheating season. During the heating season, the daily NP concentrations tended to be larger (Figure 3), whereas during the nonheating season, there were several cases with higher NP concentrations during nighttime (Figure 4).

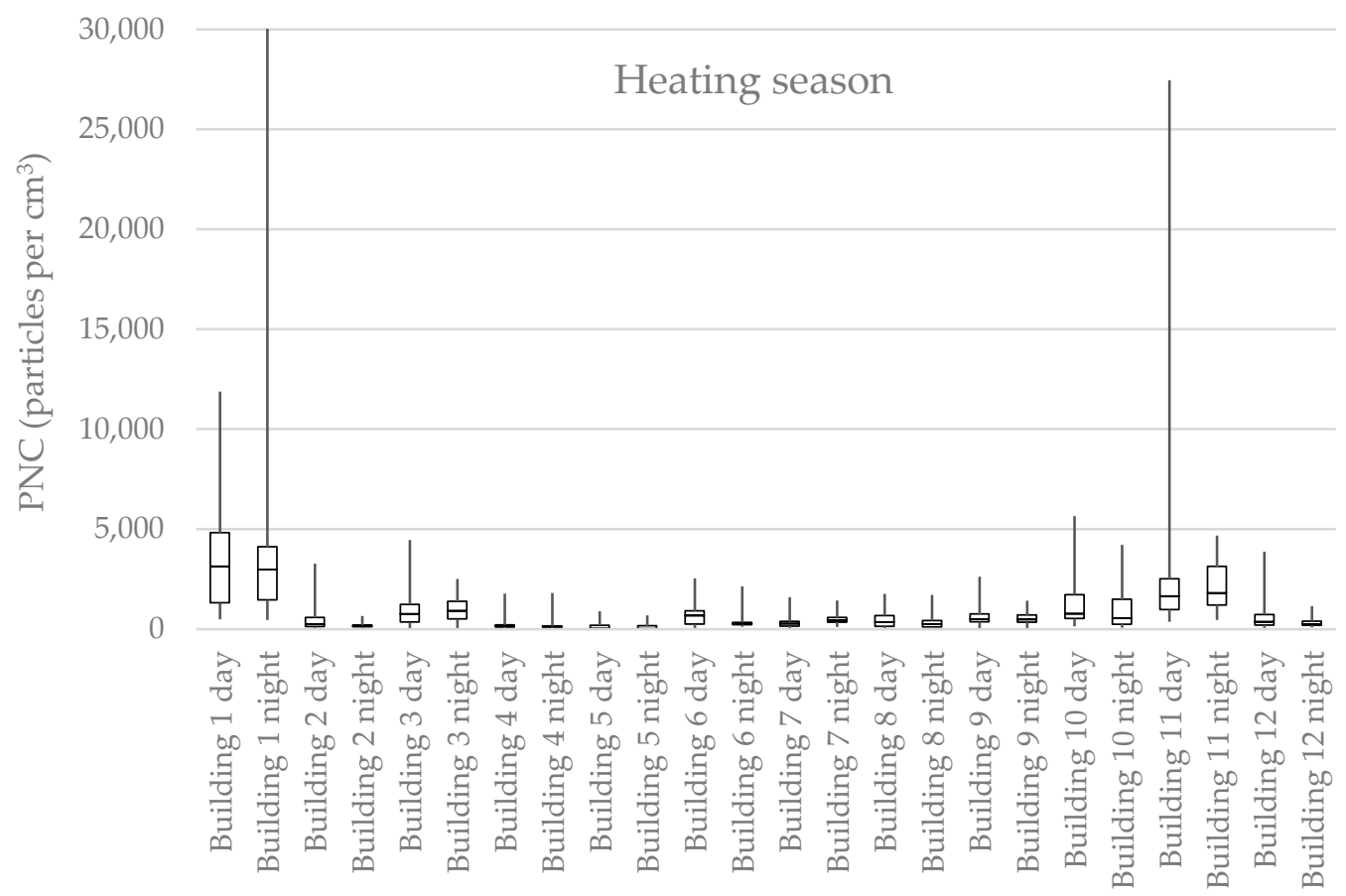

Figure 3. Mean, 25th, and 75th percentile and min and max values for the NP number concentrations in twelve office buildings during daytime (from 6 a.m. until 6 p.m.) and nighttime (from 6 p.m. until 6 a.m.) during a one-week measuring period in the heating season. 
Table 2. Average concentrations of measured NPs ( $\leq 461 \mathrm{~nm})$, ultrafine particles $(<100 \mathrm{~nm})$, and average sizes of NPs in twelve office buildings in Umeå during the heating and nonheating seasons, and the buildings' distances from a busy street. The buildings and their numbers are presented in Figure 1.

\begin{tabular}{|c|c|c|c|c|c|c|c|}
\hline \multirow{3}{*}{$\begin{array}{c}\text { Buildings } \\
1-12\end{array}$} & \multirow{2}{*}{\multicolumn{2}{|c|}{$\begin{array}{c}\text { Daytime }^{1} \\
\text { Concentration } \\
\left(\text { Particles per } \mathrm{cm}^{3}\right)\end{array}$}} & \multicolumn{4}{|c|}{ Nighttime $^{2}$} & \multirow{3}{*}{$\begin{array}{l}\text { Distance } \\
\text { from Busy } \\
\text { Street (m) }\end{array}$} \\
\hline & & & \multirow{2}{*}{$\begin{array}{l}\text { Size } \\
(\mathrm{nm})\end{array}$} & \multicolumn{2}{|c|}{$\begin{array}{c}\text { Concentration } \\
\left(\text { Particles per } \mathrm{cm}^{3}\right)\end{array}$} & \multirow{2}{*}{$\begin{array}{l}\text { Size } \\
(\mathrm{nm})\end{array}$} & \\
\hline & $<100 \mathrm{~nm}$ & $\leq 461 \mathrm{~nm}$ & & $<100 \mathrm{~nm}$ & $\leq 461 \mathrm{~nm}$ & & \\
\hline \multicolumn{8}{|c|}{ Heating season } \\
\hline 1 & 2980 & 3224 & 44 & 3054 & 3336 & 49 & 850 \\
\hline 2 & 366 & 458 & 73 & 144 & 178 & 66 & 790 \\
\hline 3 & 725 & 867 & 59 & 853 & 970 & 58 & 700 \\
\hline 4 & 153 & 208 & 69 & 149 & 163 & 56 & 500 \\
\hline 5 & 22 & 37 & 92 & 20 & 34 & 91 & 860 \\
\hline 6 & 392 & 651 & 93 & 202 & 305 & 97 & 920 \\
\hline 7 & 251 & 315 & 67 & 419 & 488 & 64 & 970 \\
\hline 8 & 381 & 499 & 65 & 251 & 310 & 77 & 570 \\
\hline 9 & 492 & 625 & 69 & 430 & 532 & 68 & 680 \\
\hline 10 & 1014 & 1233 & 63 & 814 & 1037 & 71 & 250 \\
\hline 11 & 2152 & 2366 & 40 & 1924 & 2091 & 37 & 130 \\
\hline 12 & 503 & 623 & 67 & 231 & 313 & 79 & 550 \\
\hline \multicolumn{8}{|c|}{ Nonheating season } \\
\hline 1 & 545 & 648 & 73 & 921 & 1096 & 62 & 850 \\
\hline 2 & 304 & 423 & 85 & 164 & 227 & 87 & 790 \\
\hline 3 & 1117 & 1275 & 64 & 855 & 1069 & 70 & 700 \\
\hline 4 & 503 & 815 & 87 & 365 & 574 & 89 & 500 \\
\hline 5 & 545 & 617 & 67 & 681 & 841 & 61 & 860 \\
\hline 6 & 910 & 1079 & 61 & 1300 & 1405 & 57 & 920 \\
\hline 7 & 326 & 456 & 75 & 400 & 481 & 68 & 970 \\
\hline 8 & 339 & 566 & 100 & 375 & 596 & 98 & 570 \\
\hline 9 & 723 & 1174 & 93 & 773 & 1156 & 92 & 680 \\
\hline 10 & 486 & 858 & 105 & 560 & 937 & 103 & 250 \\
\hline 11 & 456 & 609 & 76 & 378 & 548 & 81 & 130 \\
\hline 12 & 387 & 572 & 86 & 429 & 670 & 83 & 550 \\
\hline
\end{tabular}

${ }^{1}$ From 6 a.m. until 6 p.m. ${ }^{2}$ From 6 p.m. until 6 a.m.

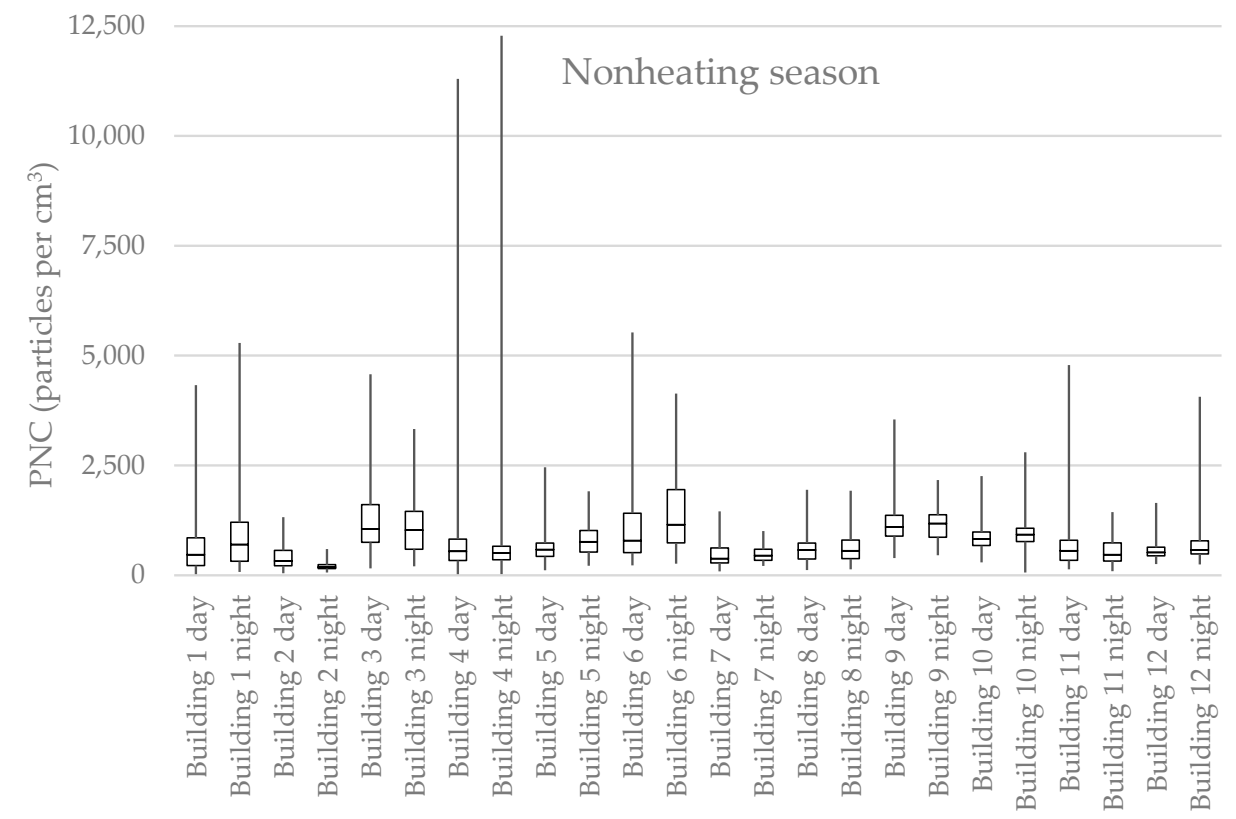

Figure 4. Mean, 25th, and 75th percentile and min and max values for the NP number concentrations in twelve office buildings during daytime (from 6 a.m. until 6 p.m.) and nighttime (from 6 p.m. until 6 a.m.) during a one-week measuring period in the nonheating season. 
Subsequently, we also calculated the concentration of NPs smaller than $100 \mathrm{~nm}$, also called ultrafine particles (Table 2). In the offices with the highest number concentrations, at least $80-90 \%$ of the particles were $<100 \mathrm{~nm}$. During the nonheating season, the fraction of particles $<100 \mathrm{~nm}$ was relatively smaller in comparison with the heating season. The average size of the NPs varied from 37 to $105 \mathrm{~nm}$, being relatively smaller during the heating season (Table 2). Average temperature and average relative humidity during the measurements are presented in Table A1, Appendix A.

\subsection{Diurnal Cycles of Nanoparticle Concentrations and the Ventilation Flows}

The NP concentrations and the simultaneous ventilation flows in the five most characteristic buildings are presented in Figures 5-10. The buildings were chosen in order to represent buildings with: (1) variable and (2) more constant ventilation flow and (3) different distances from a busy street. Building 1 represents a newly completed building where the ventilation was not yet properly working (switched off during two working days) (Figure 5). In some cases, an increase in NP concentration can be seen after ventilation turnon or increase in capacity. In Buildings 3 and 7, the ventilation flow was decreased during nighttime and weekends (Figures 6 and 7). Nevertheless, the effect on NP concentrations cannot be seen in Building 3, and a tendency of anticorrelation is shown in Building 7. Building 8 had sensor-controlled ventilation in the office rooms, and these systems were switched off during nighttime and weekends (Figure 8). Here, there were several days with a decrease in NP concentrations in connection with the systems being switched off, and an increase in connection with the system being switched on again (Figure 8).

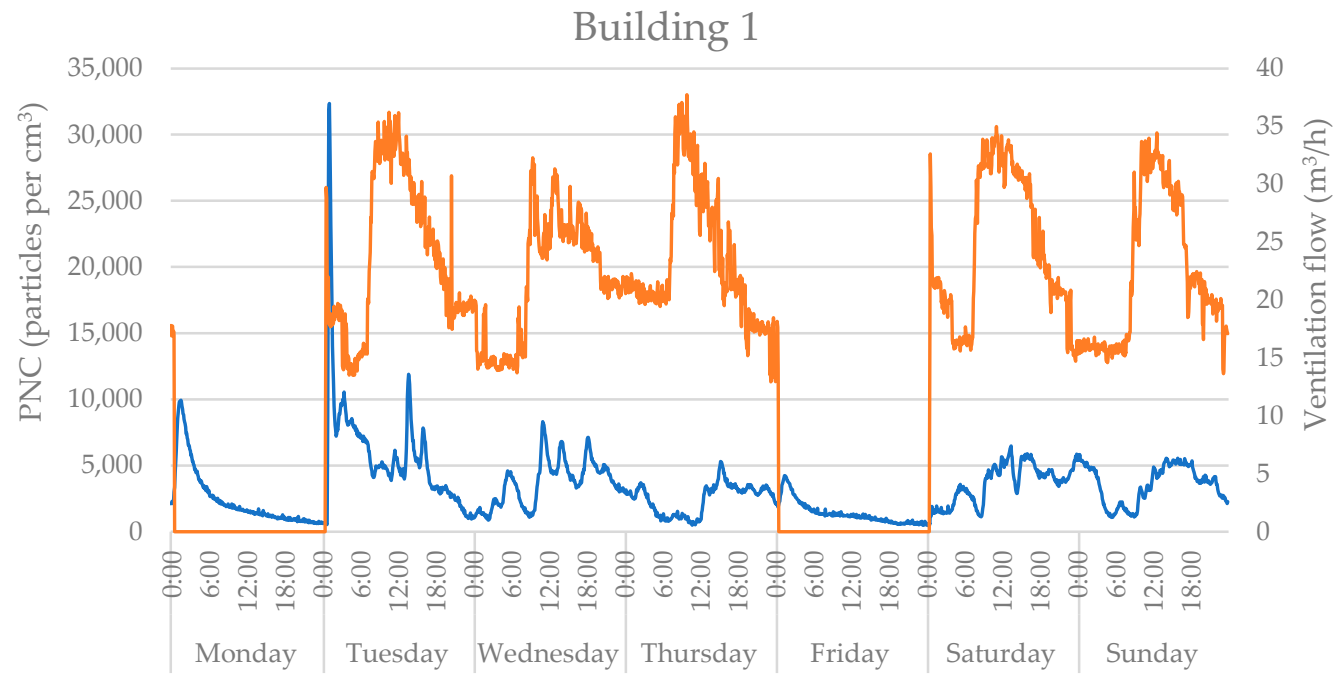

Figure 5. The NP number concentration (blue line) and the ventilation flow (orange line) in Building 1 during the heating season. The NP concentrations and the ventilation flow were measured in five-minute intervals. 


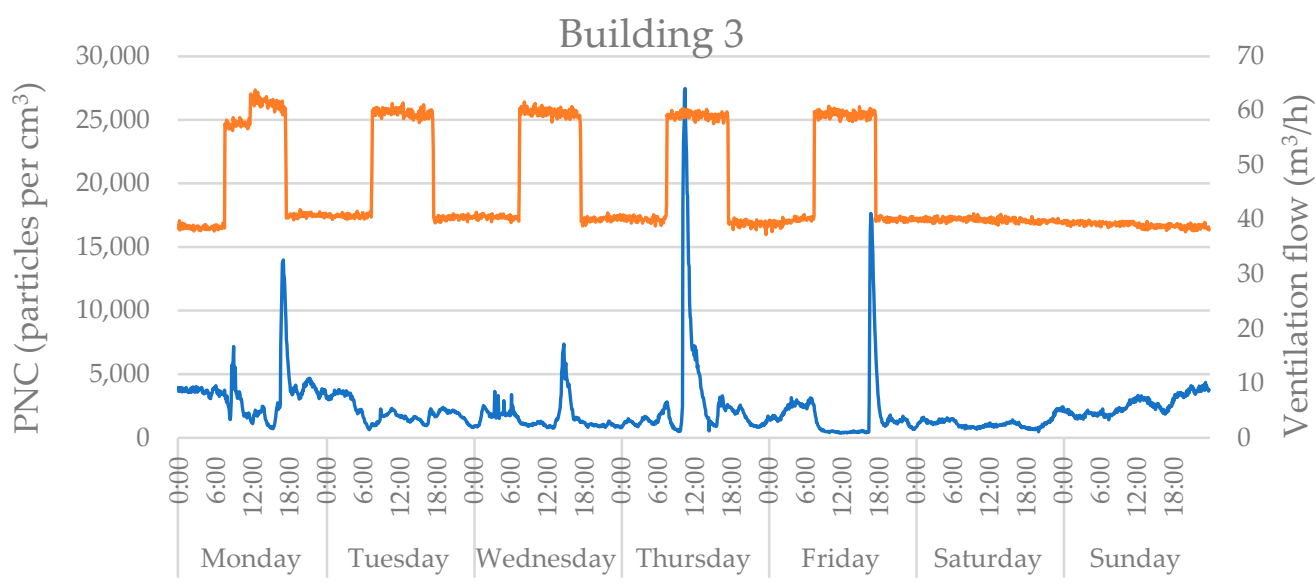

Figure 6. The NP number concentration (blue line) and the ventilation flow (orange line) in Building 3 during the heating season. The NP concentrations and the ventilation flow were measured in five-minute intervals.

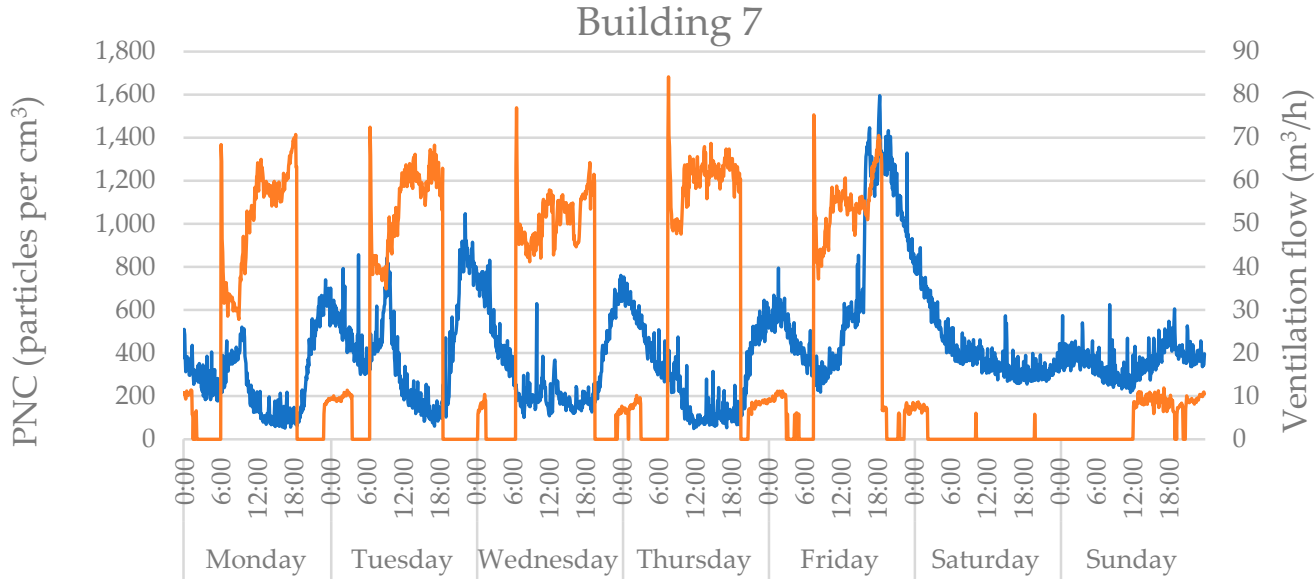

Figure 7. The NP number concentration (blue line) and the ventilation flow (orange line) in Building 7 during the heating season. The NP concentrations and the ventilation flow were measured in five-minute intervals.

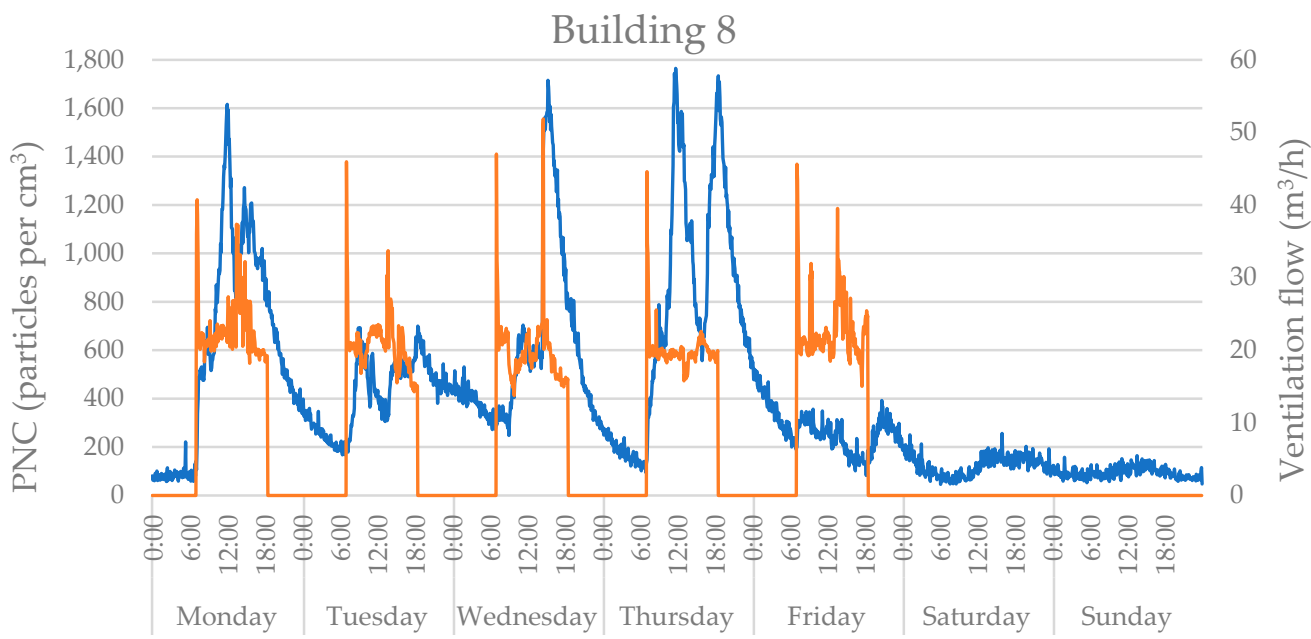

Figure 8. The NP number concentration (blue line) and the ventilation flow (orange line) in Building 8 during the heating season. The NP concentrations and the ventilation flow were measured in five-minute intervals. 


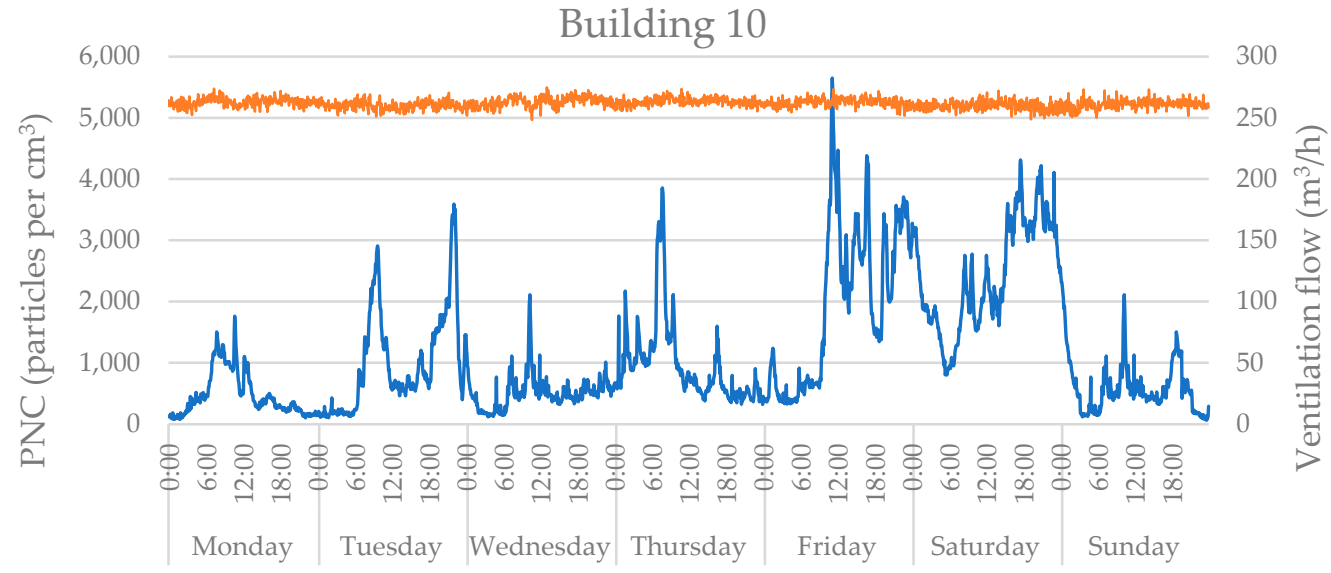

Figure 9. The NP number concentration (blue line) and the ventilation flow (orange line) in Building 10 during the heating season. The NP concentrations and the ventilation flow were measured in five-minute intervals.

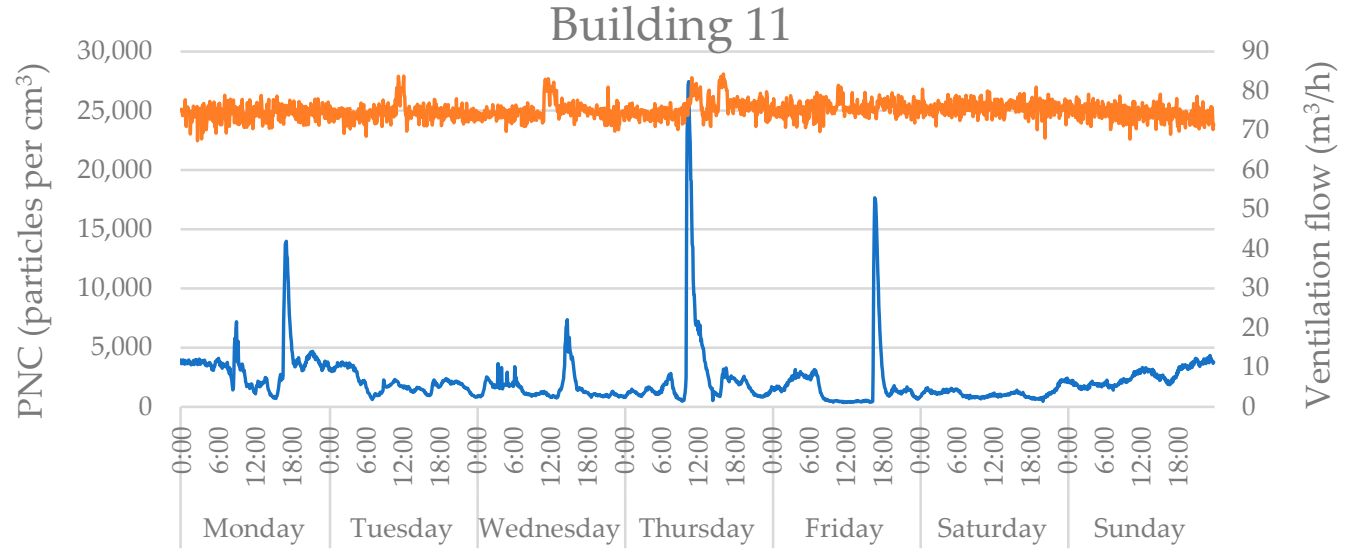

Figure 10. The NP number concentration (blue line) and the ventilation flow (orange line) in Building 11 during the heating season. The NP concentrations and the ventilation flow were measured in five-minute intervals.

Buildings 10 and 11 (Figures 9 and 10) had more or less constant ventilation flow 24/7, and the flows were significantly higher compared to the other four analyzed buildings (Figures 5-8). Moreover, there were large variations in the NP concentrations that cannot be related to the ventilation flows. Nevertheless, those two were also the buildings located closest to a busy street that might have larger influence of ambient air pollution, especially in terms of combustion-formed NPs.

\subsection{Size Fractions of Nanoparticles}

In Appendix A (Figures A1-A24), the average concentrations of NPs in all 107 size fractions during the one-week measurement periods are presented for the twelve buildings during the heating and the nonheating seasons. Moreover, large variations between the buildings appeared with particularly high NP concentrations during the heating season in Buildings 1, 10, and 11. In almost all buildings, the dominating size fractions were smaller during the heating season compared to the nonheating season. The concentrations of NPs in the size range of 10-15 nm and/or 15-20 nm were relatively lower compared to the concentrations in the larger size fractions. The size fractions in some of the buildings were more equally divided (Figures A4, A5, A7-A9, A11, A15-A17, A19, A22 and A23), whereas in the other buildings, a high peak on certain fractions appeared (Figures A1-A3, A6, A10, A12-A14, A18, A20, A21 and A24). 


\subsection{The Correlation Coefficients (Pearson) between the Ventilation Flow and the NP} Concentrations at Different Size Fractions

In order to determine the filtration efficiency at different particle size fractions, the correlation coefficients between the ventilation flows and the NP concentrations measured during the whole one-week measurement periods were calculated. These correlation coefficients are presented in Figures 11-14. The figures were selected in order to include buildings with a variable ventilation flow throughout the day and the night during the whole measurement week.

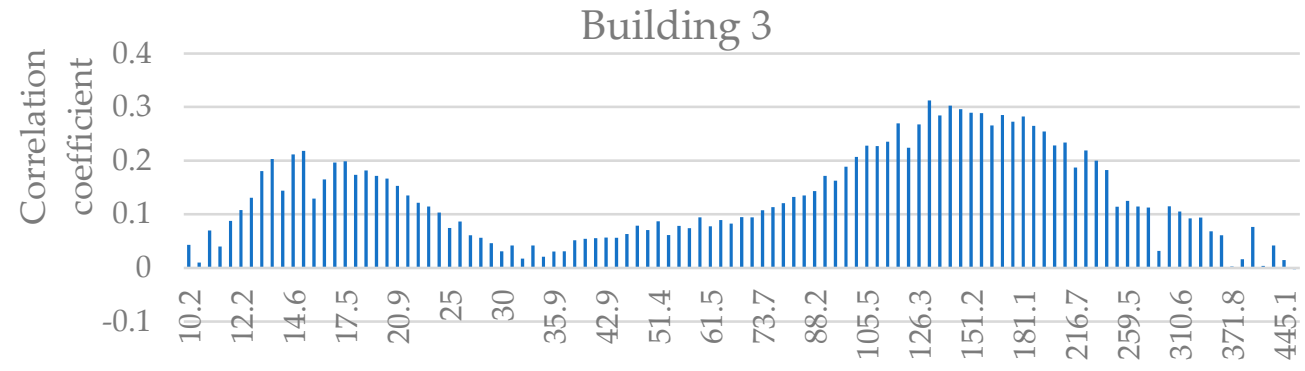

The measured NP size fractions (nm)

Figure 11. The correlation coefficients (Pearson) between the ventilation flow and the NP number concentration during the one-week measurement period presented for each size fraction in Building 3 during the heating season.

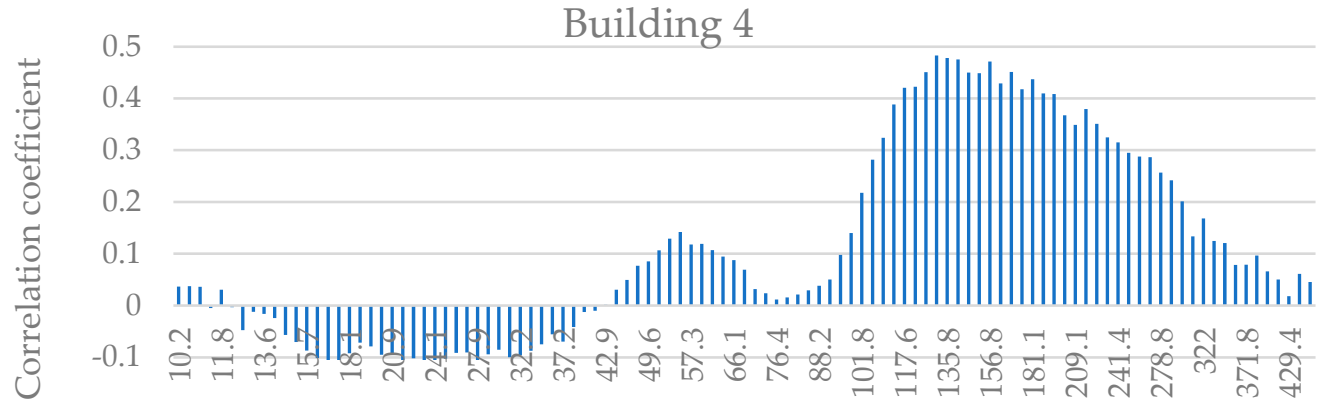

The measured NP size fractions (nm)

Figure 12. The correlation coefficients (Pearson) between the ventilation flow and the NP number concentration during the one-week measurement period presented for each size fraction in Building 4 during the heating season.

\section{Building 7}

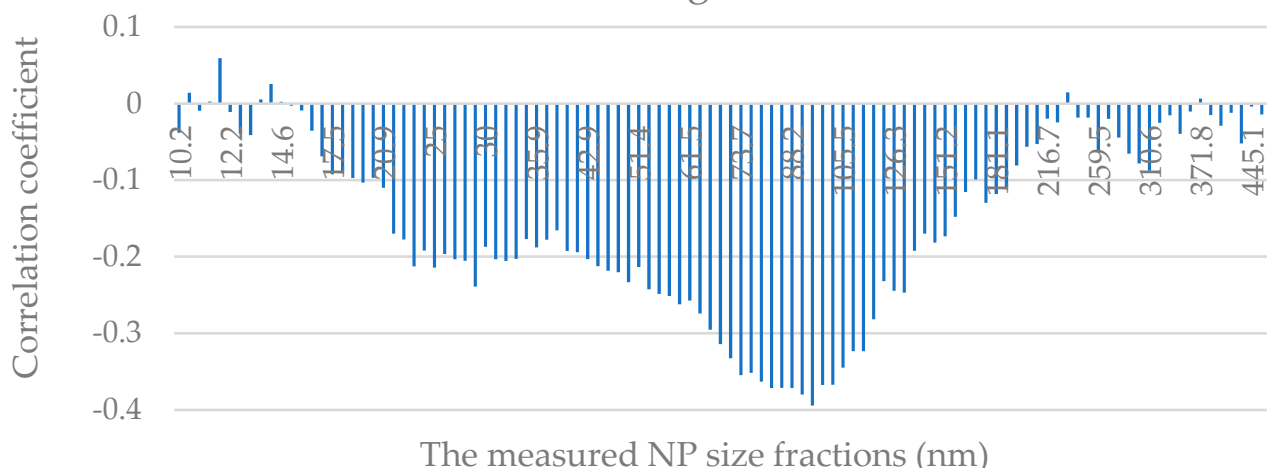

Figure 13. The correlation coefficients (Pearson) between the ventilation flow and the NP number concentration during the one-week measurement period presented for each size fraction in Building 7 during the heating season. 


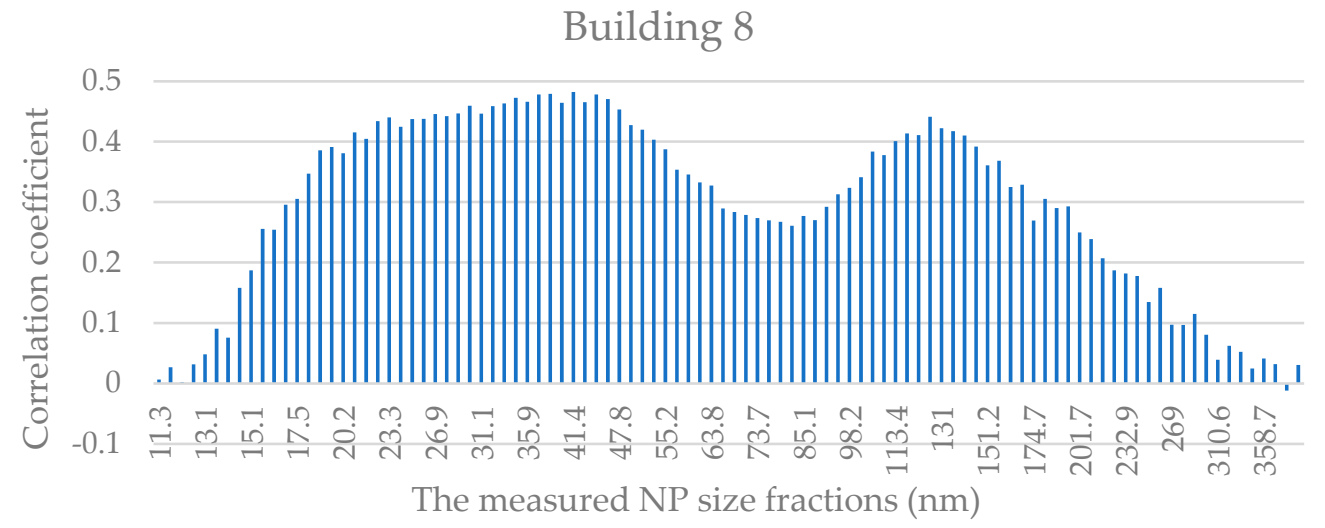

Figure 14. The correlation coefficients (Pearson) between the ventilation flow and the NP number concentration during the one-week measurement period presented for each size fraction in Building 8 during the heating season.

The correlation coefficients in Figures 11-14 were in general relatively low in the size fractions of 10-20 nm. In Figure 13 (Building 7), negative correlations were in general shown during the entire size range. Building 7 was located furthest away from a busy street (Table 2).

\section{Discussion}

\subsection{The NP Concentrations and the Impact of the Ventilation Flow}

The NP concentrations measured indoors and the simultaneous ventilation flow presented in Figures 5-10 showed mixed results. Since the NP concentrations measured indoors were a combination of particles generated both indoors and outdoors, the ventilation flow can lead to both increasing and decreasing NP concentrations. The particles generated outdoors that infiltrate the indoor environment through the ventilation system can be assumed to correlate with the amount of ventilation flow. Stasiulaitiene et al. [25] found in energy efficient buildings that the ventilation regime with minimum natural and no mechanical ventilation resulted in the lowest infiltration of outdoor pollutants. However, in this study, this effect appeared only in some of the buildings (e.g., Building 1 and 8) but not in the other buildings. Karjalainen et al. [15] have earlier discussed that particles in different size fractions were filtered to varying degrees by the ventilation filters, and since Figures 5-10 are based on the total NP concentrations, only the outdoor generated particles that were not captured by the filters can be assumed to correlate with the size of the ventilation flow. In Building 8 (Figure 8), a certain degree of correlation could be observed. Building 8 was located relatively close to a busy street, and it was equipped with a sensor-controlled ventilation system switching off during nighttime and on weekends, which may partly explain the results. In Building 7 (Figure 7), the NP concentrations and the ventilation flow exhibited a certain anticorrelation. Building 7 was located furthest away from a busy street and can be assumed to have relatively low concentrations of traffic-generated particles in the outdoor environment, and with a relatively greater impact from indoor sources of NPs. In Buildings 10 and 11 (Figures 9 and 10), the NP concentrations fluctuated sharply despite the fact that the ventilation flows were fairly constant throughout the measurement periods. These buildings were located closest to a busy street where fluctuations in the flow of traffic might have affected the results.

In the case of indoor sources, the ventilation flow was a crucial factor in removing particles from the buildings, and therefore, anticorrelations between the concentrations of indoor generated particles and the ventilation flow are expected. Since the chemical composition of the NPs measured in this study was not analyzed, it was not possible to distinguish the origin of the particles. However, in addition to NPs with outdoor origin, there are a lot of potential indoor sources of NPs that include electrical appliances [26], bioaerosols from biological materials [27], and laser printers that generate NPs in mainly 
two size classes: one smaller mode with particles $<10 \mathrm{~nm}$ and one larger mode in the size range of 40-100 nm [28]. In the current study, some of the buildings (e.g., Building 8) have sensor-controlled ventilation systems. Most often, they sense $\mathrm{CO}_{2}$ concentrations indoors, but they are often poorly correlated with the particle concentrations [29]. According to Guyot et al. [29], particle sensors could be a better option in terms of level of precision and accuracy. However, they are still expensive, but they are quickly becoming more competitive.

\subsection{The Filters Used in the Ventilation Systems and Their Impact on the Particle Concentrations}

As mentioned in Section 2, the filter type F7 was used in all buildings except Building 10 where the filter type M6 was used. Building 11 was also equipped with the filter type F9, but the measurements were carried out in the part of the building where the air was filtered by F7 filters. Building 1 was security classified without information on filter type, but as it was a new building, it had filters $\geq$ F7. The ability of filter class F7 to absorb particles in different size fractions has also been analyzed in previous studies. The filtration efficiency of particles in F7 filters is mainly driven by diffusion, impaction, and interception processes in the filter media [30]. During test conditions, where an aerosol generator was used in order to generate particles in the nucleation mode (mean particle diameter of $11 \mathrm{~nm}$ ) and the soot mode (mean particle diameter of $55 \mathrm{~nm}$ ), the filtration efficiency of F7 filters varied with respect to the size of the particles. The collection efficiency was almost $100 \%$ for particles in the size range up to $10 \mathrm{~nm}$, but decreased steeply in the particle size range above $20 \mathrm{~nm}$ [15]. Similar results regarding the efficiency of F7 filters have been demonstrated by Shi [30]. The reason for the very high collection efficiency for particles smaller than $20 \mathrm{~nm}$ is that the diffusion movement of particles increases in smaller particle sizes, resulting in higher filtration efficiency [15].

Considering the size distributions of the NP concentrations measured in the twelve buildings during the heating and the nonheating season (Figures A1-A24 in Appendix A), the concentrations of NPs in the size range of 10-20 nm were in general relatively low, indicating a high collection efficiency by the F7 filters. However, there were some exceptions with relatively high particle concentrations in the size range of 10-20 nm (Figures A8, A9, A11 and A21). The highest levels of very small NPs appeared in building 11, which was the building closest to a busy street (Figure 1), and where traffic-generated particles can be assumed to be a particularly significant source. However, the peak concentrations measured during the one-week periods in the twelve office buildings were for the most part shown in the size range of 50-60 nm, representing the Aitken mode. It has previously been shown that the average size of NPs measured outdoors are considerably smaller in comparison with the NPs measured indoors [24]. For the NPs measured outdoors during the twelve one-week periods, only the total numbers of particles have been measured based on fiveminute intervals, but the numbers of particles in different size fractions are not available. However, it is reasonable to assume that particles in the size range smaller than $50 \mathrm{~nm}$, mainly emitted from traffic, enter the ventilation systems where they are absorbed by the filters. The correlation coefficients calculated between the ventilation flow and the NP concentrations in different size fractions in Figures 11-14 were inconclusive, but the relatively low values in the size range of 10-20 nm indicate an effective filtering by the F7 filters. However, since there were both indoor and outdoor sources contributing to the measured particles, the coefficients could vary depending on whether indoor sources or outdoor sources dominate.

The importance of the filtering efficiency and the use of higher efficiency filter to improve indoor air quality have been suggested by several authors [31-33]. However, the filtering efficiency of traffic exhaust at hot spot locations could be only about onethird [34]. In the case of very high NP concentrations, additional portable air cleaners with HEPA (high efficiency particulate arresting) filters could be used [35]. However, the use of higher class filters results in higher energy demand [36]. Most of the currently studied buildings use class F7 filters that have been suggested as a reasonable choice in terms of 
indoor air quality and energy use [37]. However, in terms of public health, the higher class filters could be suggested as relatively high concentrations of NPs were found in several buildings that were studied. Additionally, Waring et al. [38] stated that despite higher energy demands and price, those costs are minor in comparison with the estimated public health benefits.

\subsection{Strengths and Limitations of This Study}

A main strength of this study is that it provides continuous measurements of nanoparticles indoors in twelve office buildings representing both the heating and nonheating seasons. The buildings were chosen to represent different ventilation systems and various distances from busy streets. The measurement periods lasted for one week, which means that they include both weekdays and a weekend during both daytime and nighttime, presented separately in the study. Another strength of this study is that the ventilation flows in the buildings represent flows under both variable and constant conditions and show how the NP concentrations are affected by those.

One of the limitations of the current study is that all buildings except one use filters of class F7. Consequently, there is very limited information on studying the filters' effect on NP filtration in real life situations. Another limitation of this study is that the chemical composition of the NPs was not studied because it was not possible to measure with the Scanning Mobility Particle Sizer Spectrometer (SMPS). This means that it is not possible to distinguish the sources of the NPs, which would have been a great advantage when it comes to understand the importance of ventilation. Therefore, this is an important issue that needs to be addressed in future studies and measurements.

\section{Conclusions}

In this study, nanoparticles were measured in twelve office buildings during two oneweek periods representing daytime and nighttime during both the heating and nonheating season. The twelve office buildings were selected to include newer, retrofitted, and older buildings with various ventilation systems and energy efficiency. The office buildings were also chosen according to different distances from busy streets as the main source of CFNPs. The ventilation flow and the filter efficiency, and their impact on the nanoparticle concentrations in the buildings, were the two main factors analyzed.

During the measurements, large differences in NP concentrations between buildings appeared, despite the fact that similar MVHR systems were used, and most of them were equipped with class F7 filters. In some cases, an increase in NP concentration could be seen after ventilation turn-on or after an increase in the ventilation flow. There was also one case where the NP concentrations increased in connection with the ventilation being switched off or reducing its flow. However, variable particle concentrations were also shown in buildings with a fairly constant ventilation flow, which was prominent for the two buildings located closest to busy streets. The particles generated outdoors that infiltrate the indoor environment through the ventilation system can be assumed to correlate with the amount of ventilation flow. In contrast, particles generated indoors can be assumed to anticorrelate with the amount of ventilation flow.

The ability of the filters to absorb particles was also different for different size classes where smaller particles $(<20 \mathrm{~nm}$ ) were more efficiently removed due to a higher diffusion rate. The correlation coefficients between the ventilation flow and particles in different size classes were in general smallest for particles in the smallest size classes, indicating higher filtration efficiency.

Most of the currently studied buildings use class F7 filters that have been suggested as a reasonable choice in terms of indoor air quality and energy use. However, relatively high concentrations of NPs were found in several buildings, and from a health perspective, the use of higher class filters could be suggested. 
Author Contributions: Conceptualization: H.O. (Hans Orru) and A.H.; methodology: H.O. (Hans Orru) and A.H.; data analysis: H.O. (Hans Orru), A.H. and H.O. (Henrik Olstrup); writing-original draft preparation: H.O. (Henrik Olstrup) and H.O. (Hans Orru); writing-review and editing A.H. All authors have read and agreed to the published version of the manuscript.

Funding: This research was funded by FORMAS, grant number 2015-01557.

Institutional Review Board Statement: Not applicable.

Informed Consent Statement: Not applicable.

Data Availability Statement: The data presented in this study are available on request from the corresponding author.

Acknowledgments: We would like to thank Norrland University Hospital, the National Board of Housing, Building and Planning, Akademiska Hus AB, and the Swedish Energy Agency for their cooperation and for providing technical details about the buildings, especially Lars Holmström, Tomas Andersson, Lars Karlsson, Maria Hammeryd, and Simon Burman. We would also like to acknowledge Kristina Lindblom and Tanel Tamm for their technical support, and two anonymous reviewers who have reviewed this paper.

Conflicts of Interest: The authors declare no conflict of interest.

\section{Appendix A}

Table A1. Average temperature and average relative humidity in the air samples measured in the twelve office buildings during the heating and nonheating seasons.

\begin{tabular}{ccccc}
\hline \multirow{2}{*}{$\begin{array}{c}\text { Buildings } \\
\mathbf{1 - 1 2}\end{array}$} & \multicolumn{2}{c}{ Heating Season } & \multicolumn{2}{c}{ Nonheating Season } \\
\cline { 2 - 5 } & $\begin{array}{r}\text { Temperature } \\
\mathbf{(}{ }^{\circ} \mathbf{C}\end{array}$ & $\begin{array}{r}\text { Relative Humidity } \\
(\mathbf{\%} \mathbf{R})\end{array}$ & $\begin{array}{c}\text { Temperature } \\
\left({ }^{\circ} \mathbf{C}\right)\end{array}$ & $\begin{array}{c}\text { Relative Humidity } \\
(\mathbf{\%} \mathbf{H})\end{array}$ \\
\hline 1 & 22.1 & 20.9 & 22.2 & 26.3 \\
2 & 24.0 & 18.1 & 23.8 & 34.3 \\
3 & 21.9 & 19.1 & 18.8 & 28.1 \\
4 & 22.9 & 18.5 & 23.1 & 36.0 \\
5 & 23.3 & 20.6 & 25.0 & 28.5 \\
6 & 23.6 & 20.7 & 25.7 & 30.9 \\
7 & 22.8 & 14.9 & 25.5 & 32.5 \\
8 & 22.0 & 16.9 & 24.7 & 30.4 \\
9 & 23.4 & 16.4 & 23.1 & 36.0 \\
10 & 21.8 & 20.3 & 23.1 & 50.4 \\
11 & 22.2 & 15.8 & 22.5 & 25.4 \\
12 & 24.8 & 13.9 & 22.5 & 40.2 \\
\hline
\end{tabular}

\section{Building 1 (heating season)}

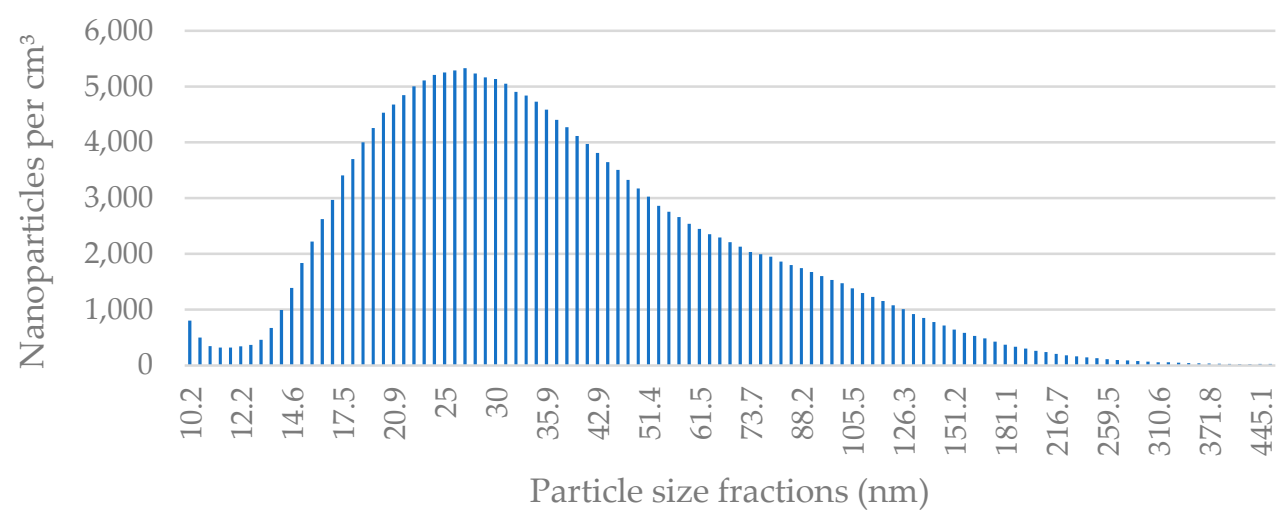

Figure A1. The average nanoparticle concentration in each size fraction in Building 1 during a one-week measurement period during the heating season. 
Building 1 (non-heating season)

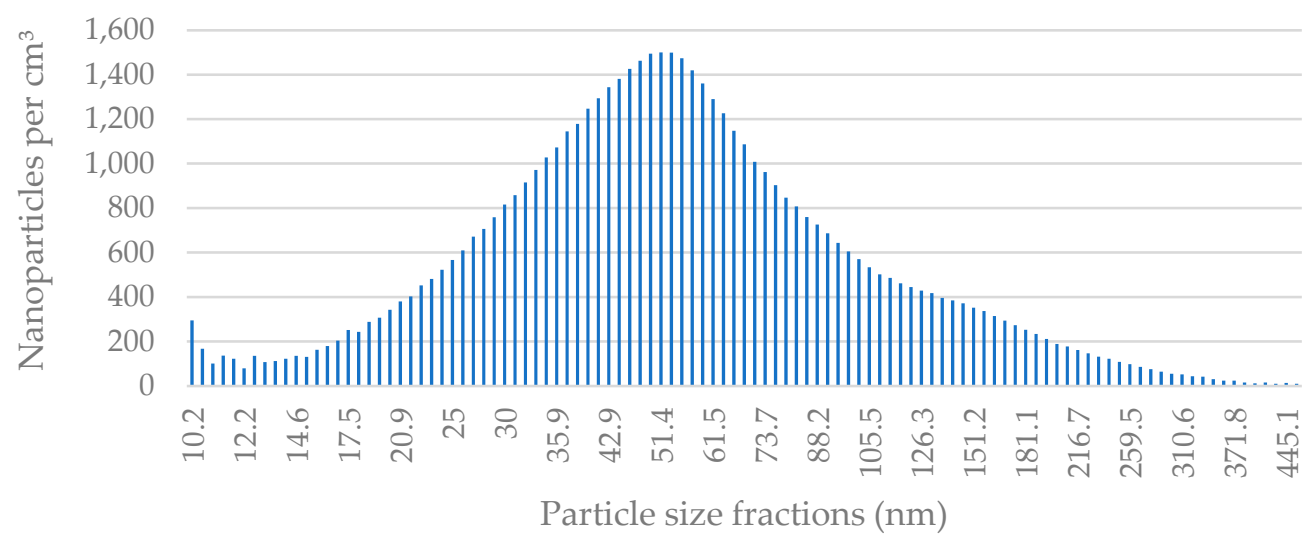

Figure A2. The average nanoparticle concentration in each size fraction in Building 1 during a one-week measurement period during the nonheating season.

\section{Building 2 (heating season)}

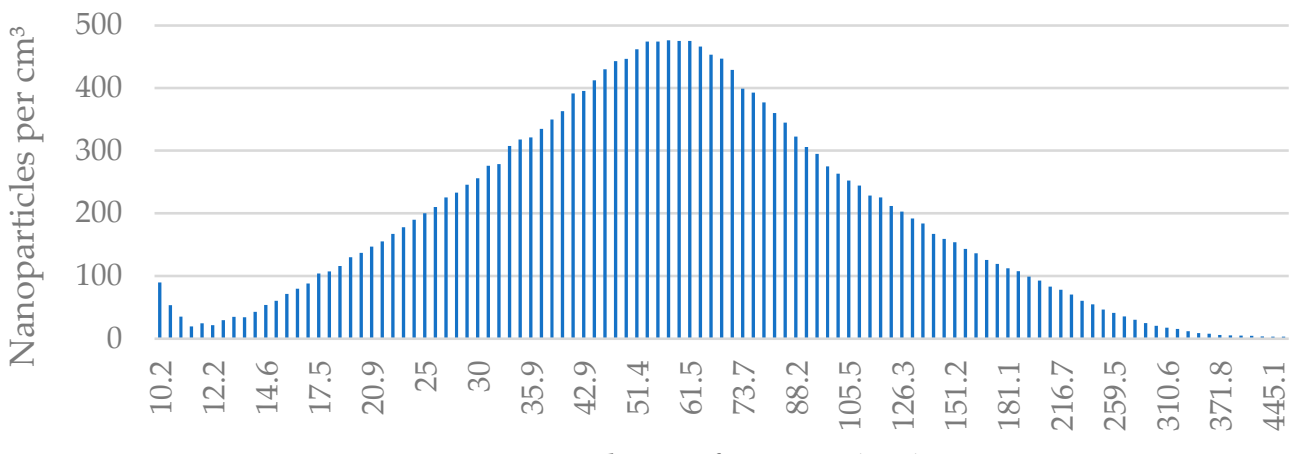

Particle size fractions $(\mathrm{nm})$

Figure A3. The average nanoparticle concentration in each size fraction in Building 2 during a one-week measurement period during the heating season.

\section{Building 2 (nonheating season)}

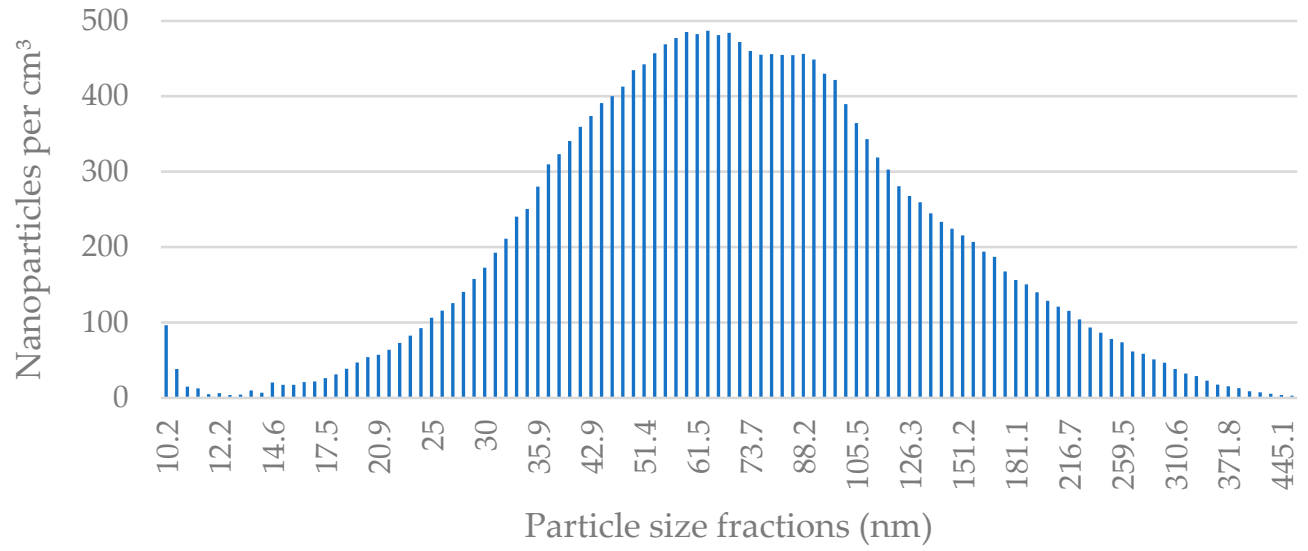

Figure A4. The average nanoparticle concentration in each size fraction in Building 2 during a one-week measurement period during the nonheating season. 
Building 3 (heating season)

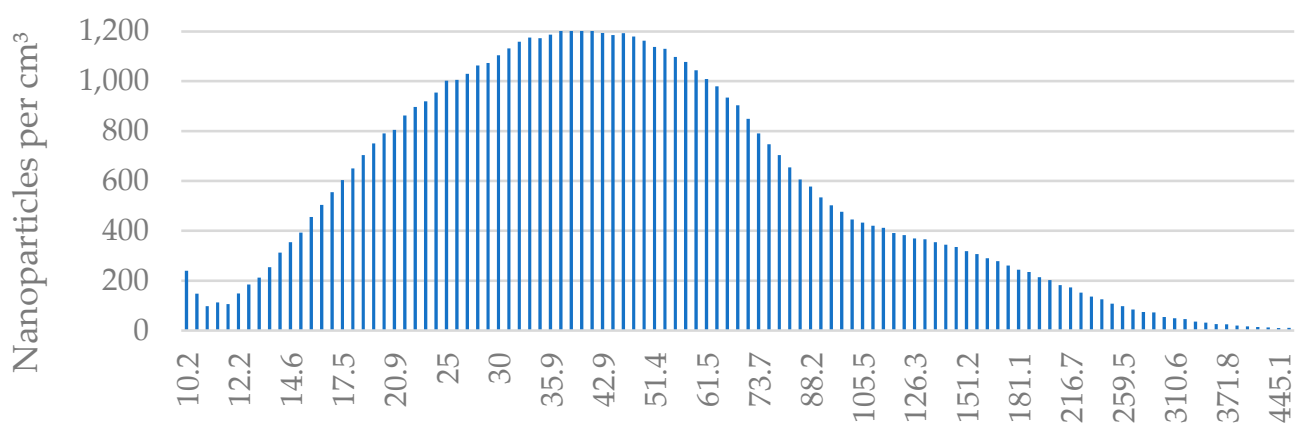

Particle size fractions (nm)

Figure A5. The average nanoparticle concentration in each size fraction in Building 3 during a one-week measurement period during the heating season.

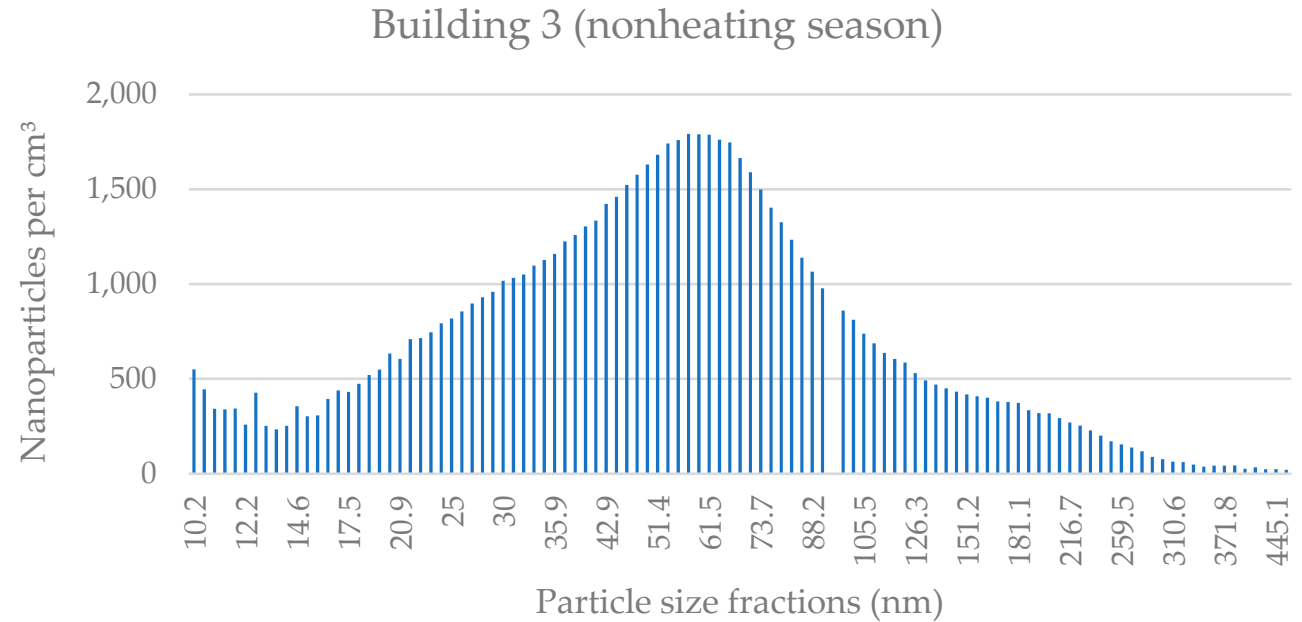

Figure A6. The average nanoparticle concentration in each size fraction in Building 3 during a one-week measurement period during the nonheating season.

\section{Building 4 (heating season)}

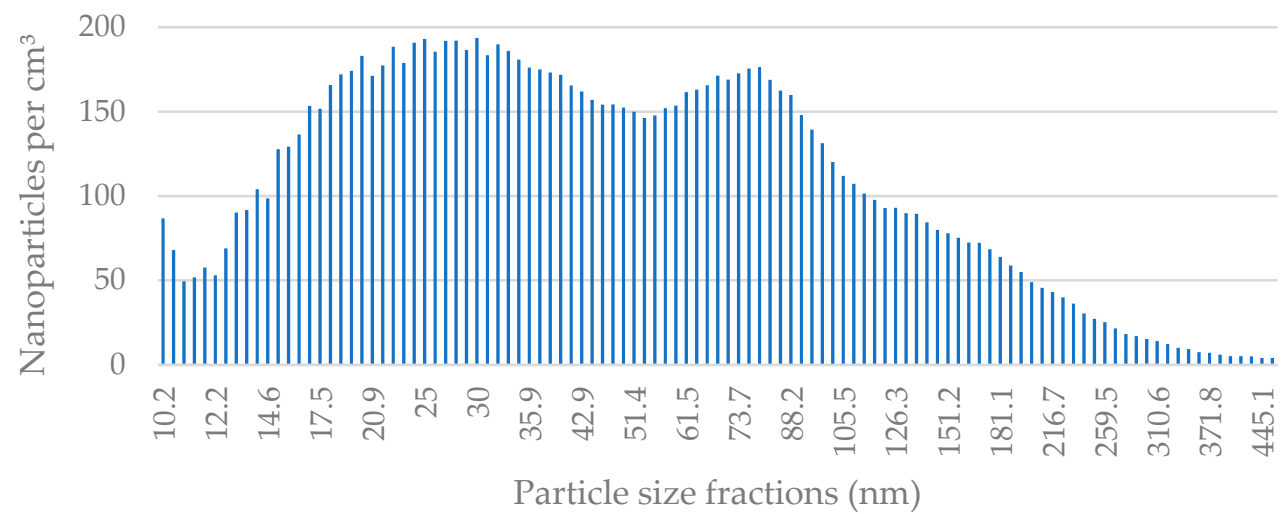

Figure A7. The average nanoparticle concentration in each size fraction in Building 4 during a one-week measurement period during the heating season. 
Building 4 (nonheating season)

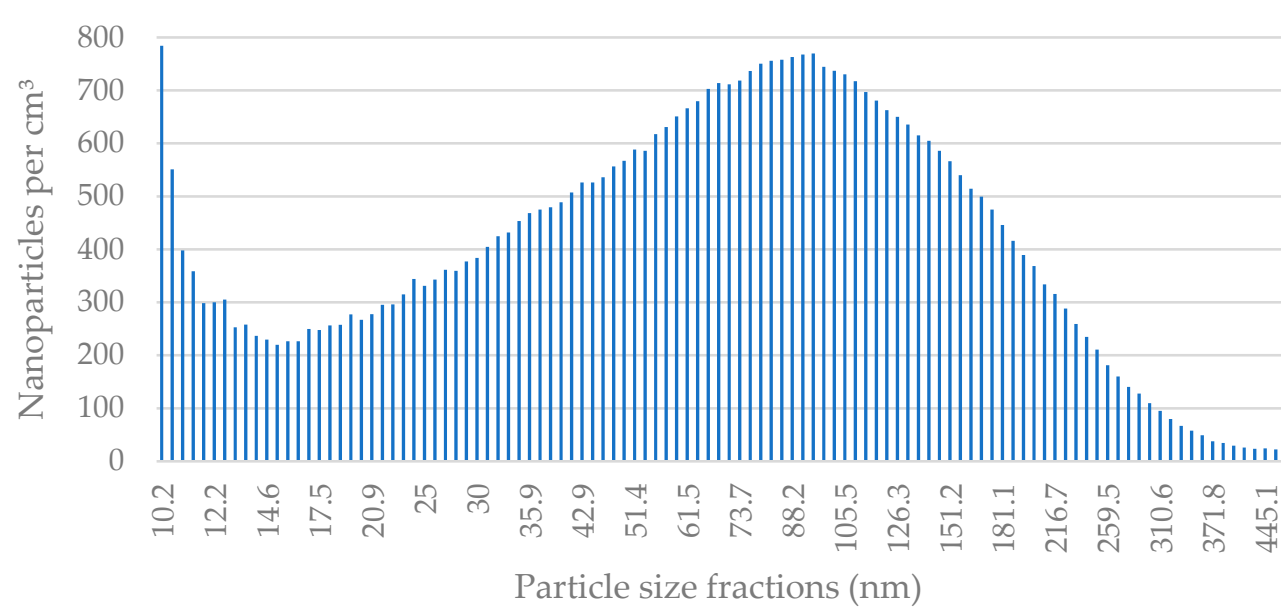

Figure A8. The average nanoparticle concentration in each size fraction in Building 4 during a one-week measurement period during the nonheating season.

\section{Building 5 (heating season)}

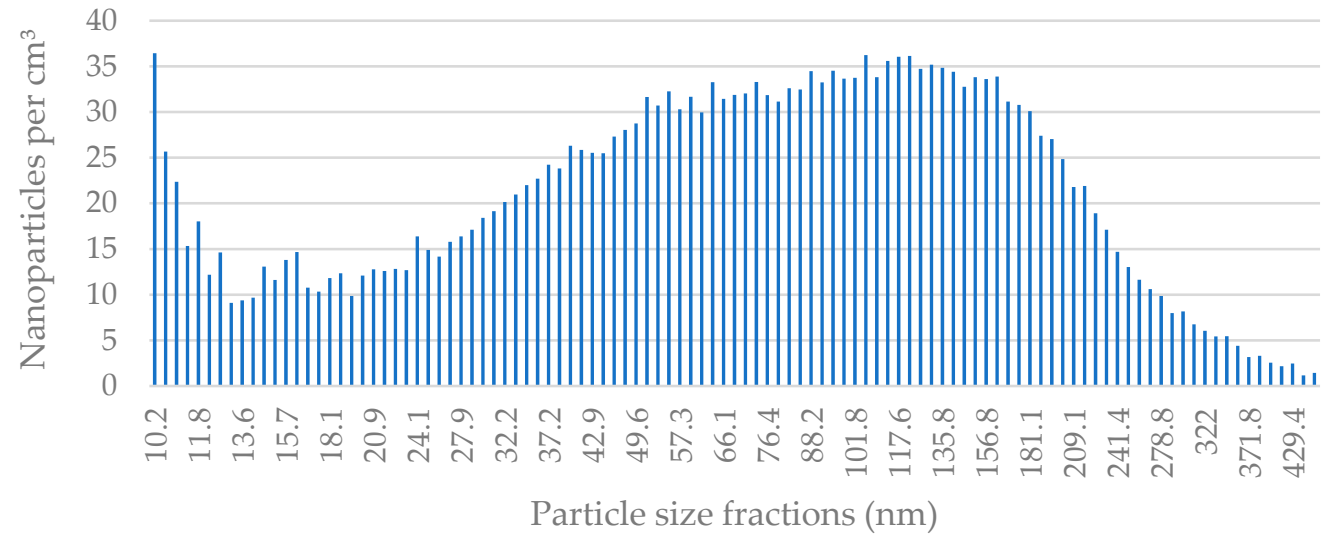

Figure A9. The average nanoparticle concentration in each size fraction in Building 5 during a one-week measurement period during the heating season.

\section{Building 5 (nonheating season)}

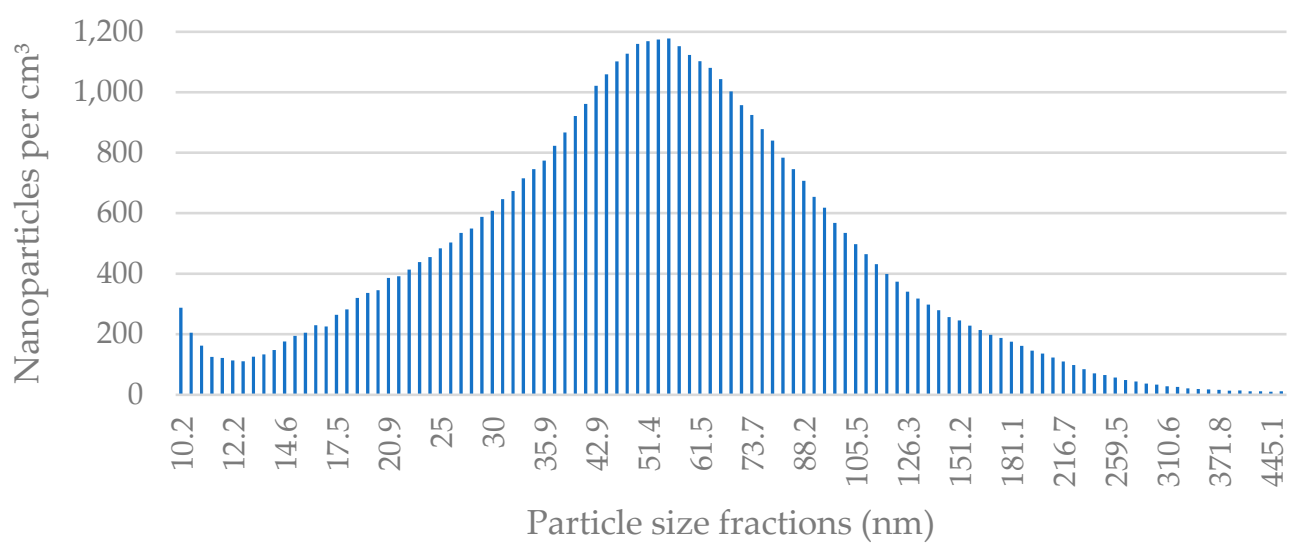

Figure A10. The average nanoparticle concentration in each size fraction in Building 5 during a one-week measurement period during the nonheating season. 


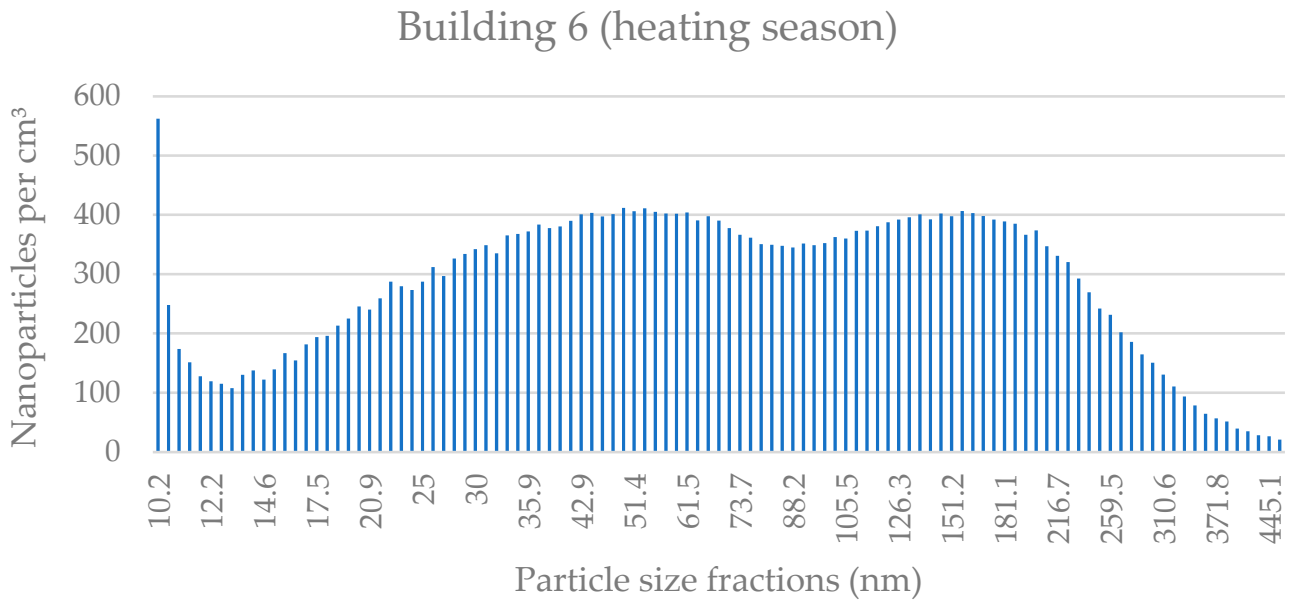

Figure A11. The average nanoparticle concentration in each size fraction in Building 6 during a one-week measurement period during the heating season.

\section{Building 6 (nonheating season)}

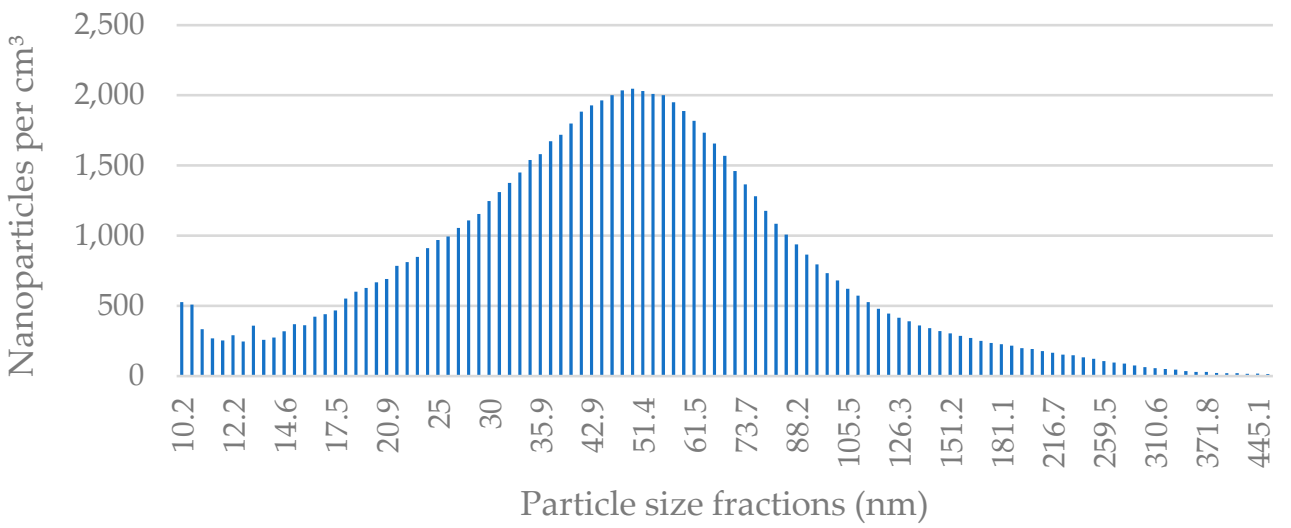

Figure A12. The average nanoparticle concentration in each size fraction in Building 6 during a one-week measurement period during the nonheating season.

\section{Building 7 (heating season)}

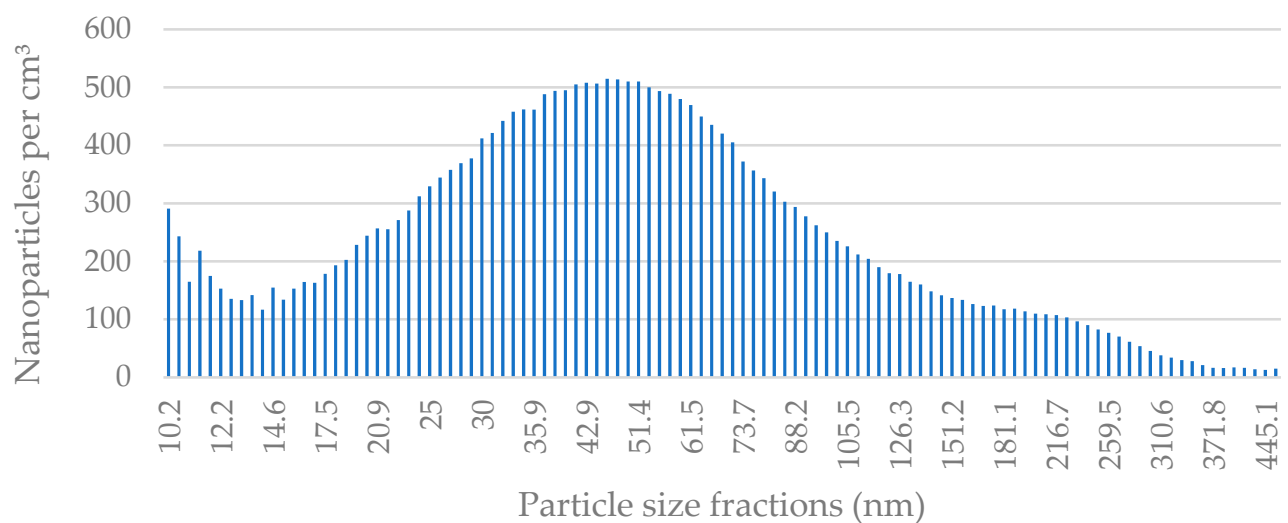

Figure A13. The average nanoparticle concentration in each size fraction in Building 7 during a one-week measurement period during the heating season. 


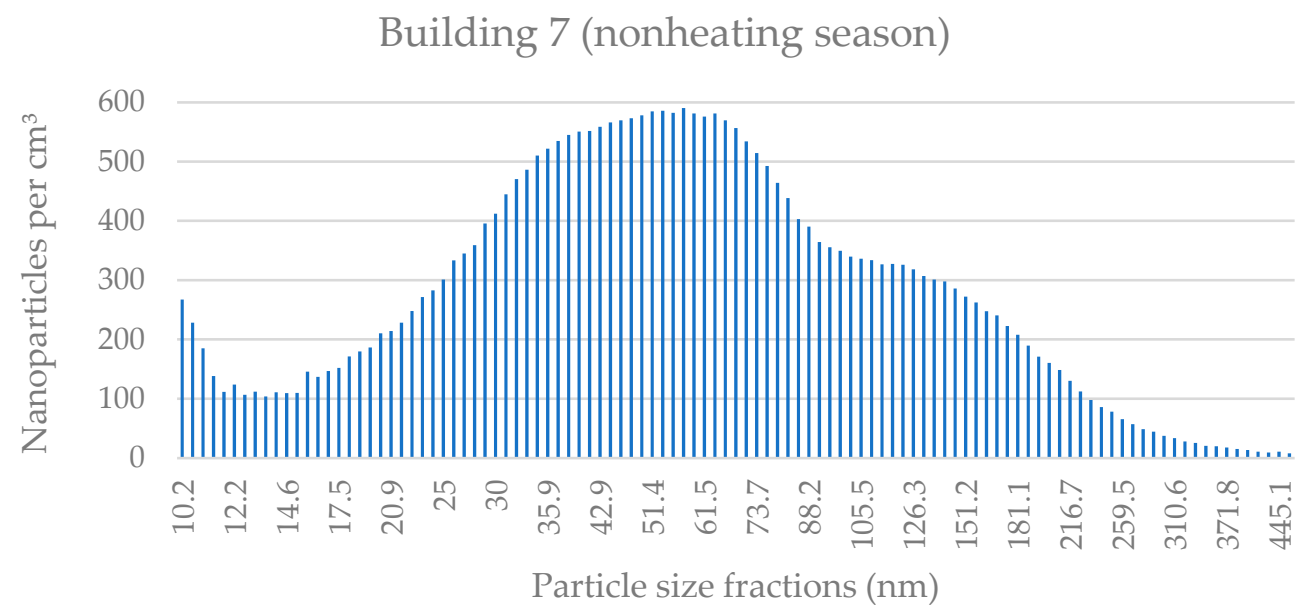

Figure A14. The average nanoparticle concentration in each size fraction in Building 7 during a one-week measurement period during the nonheating season.

\section{Building 8 (heating season)}

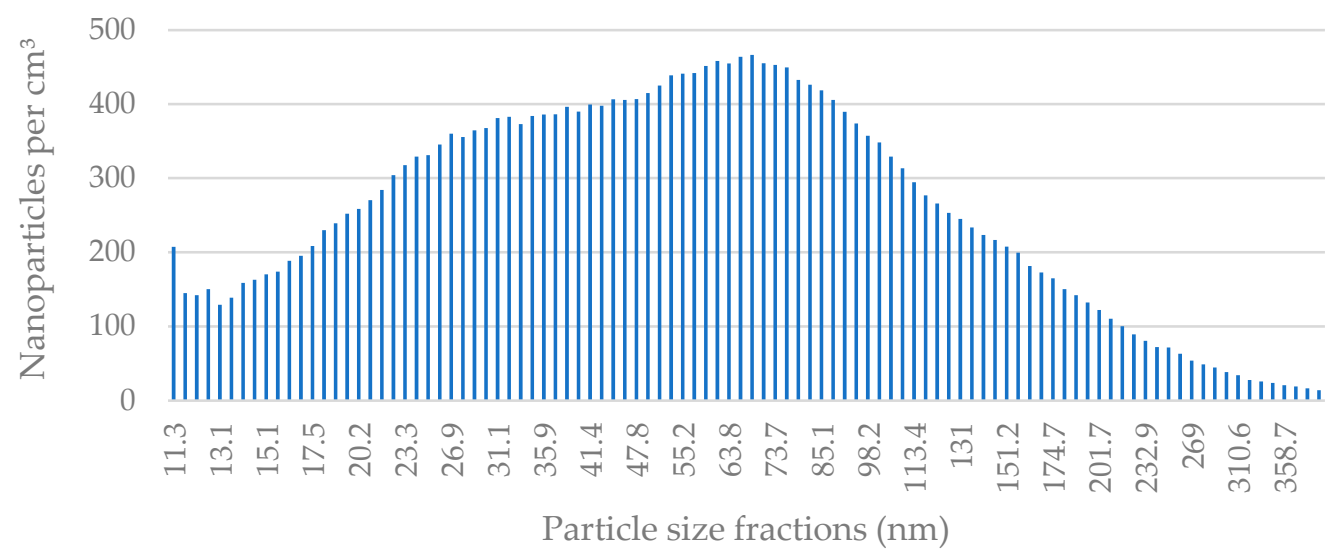

Figure A15. The average nanoparticle concentration in each size fraction in Building 8 during a one-week measurement period during the heating season.

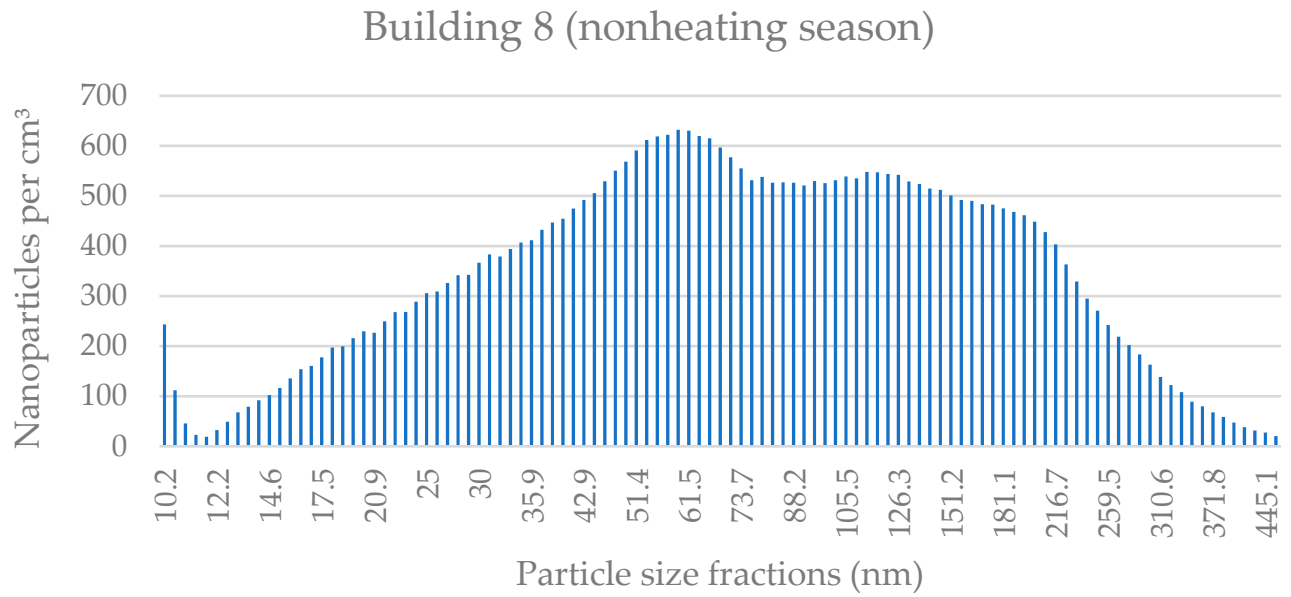

Figure A16. The average nanoparticle concentration in each size fraction in Building 8 during a one-week measurement period during the nonheating season. 
Building 9 (heating season)

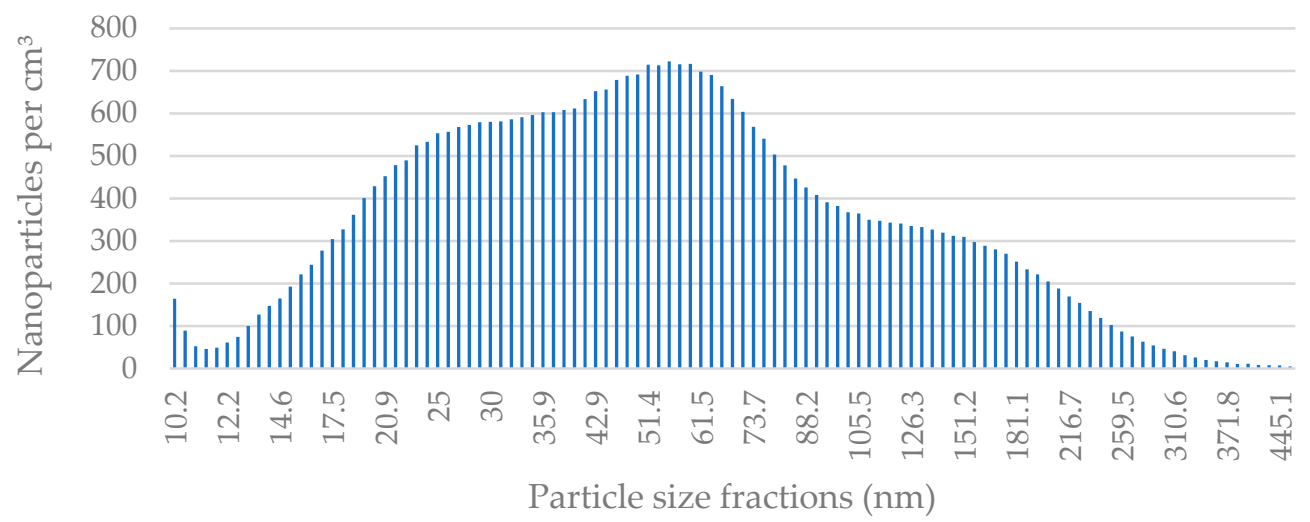

Figure A17. The average nanoparticle concentration in each size fraction in Building 9 during a one-week measurement period during the heating season.

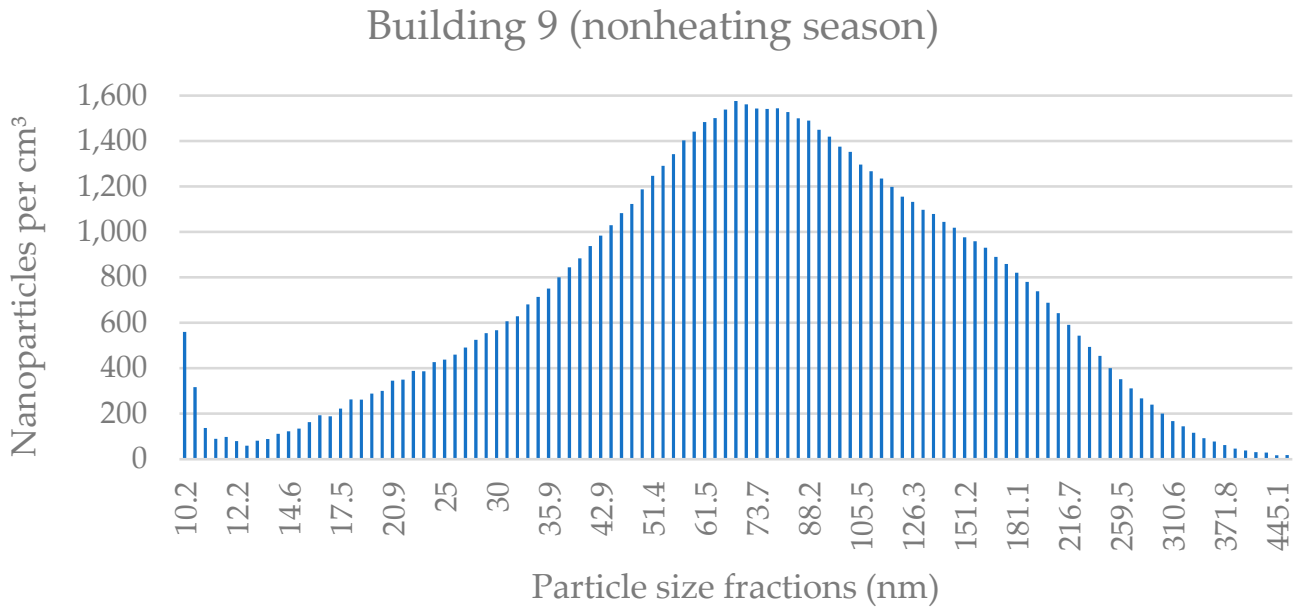

Figure A18. The average nanoparticle concentration in each size fraction in Building 9 during a one-week measurement period during the nonheating season.

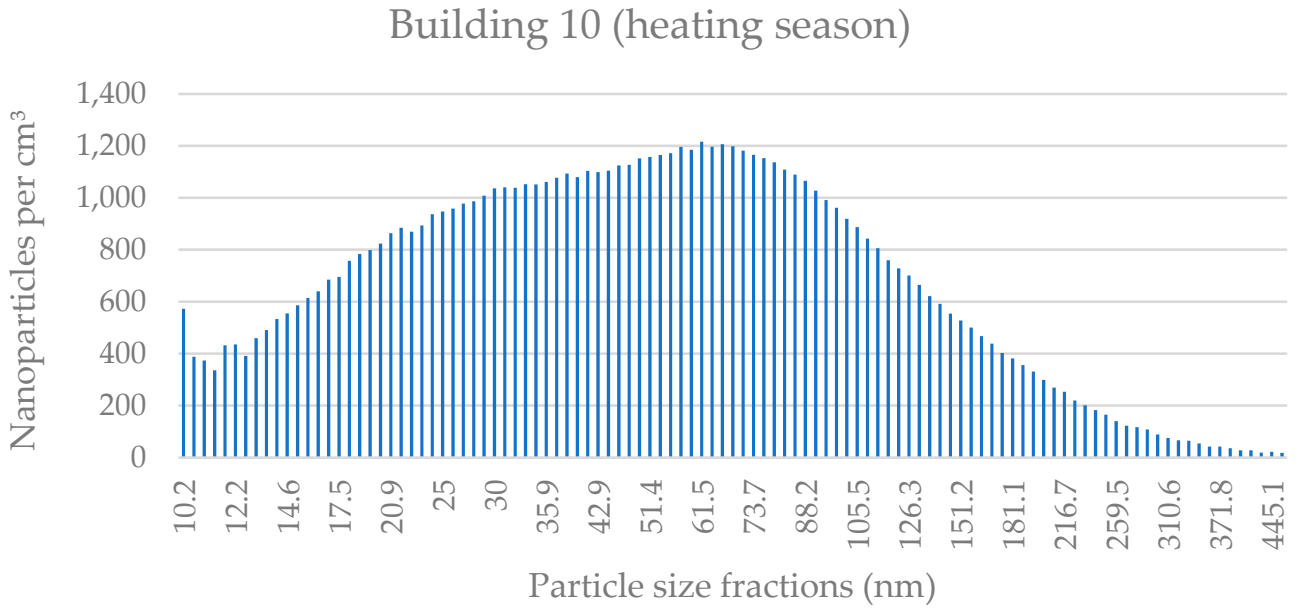

Figure A19. The average nanoparticle concentration in each size fraction in Building 10 during a one-week measurement period during the heating season. 
Building 10 (nonheating season)

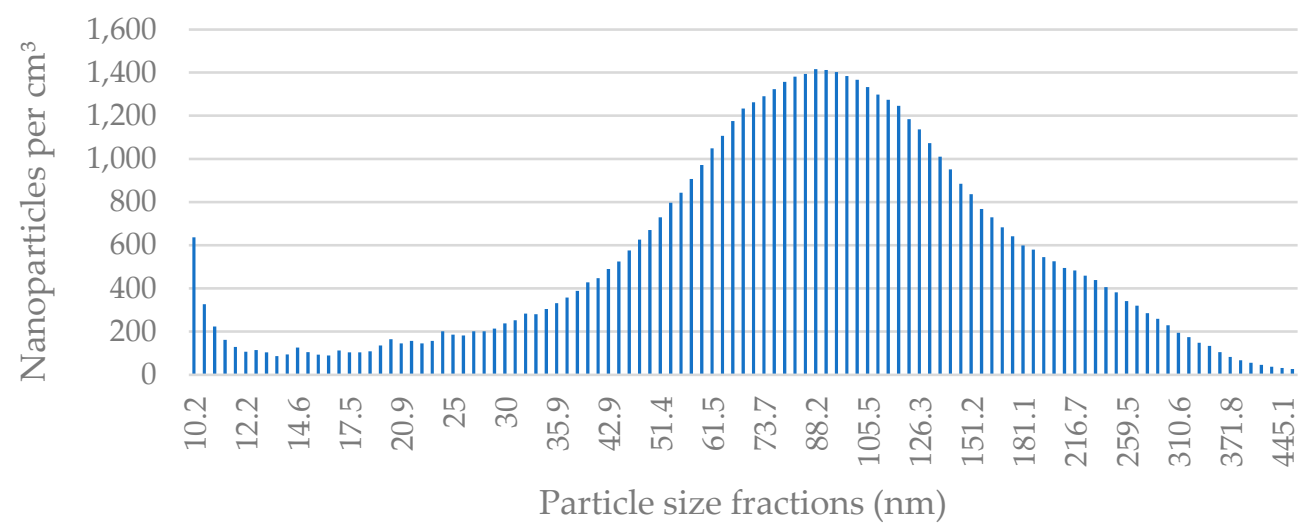

Figure A20. The average nanoparticle concentration in each size fraction in Building 10 during a one-week measurement period during the nonheating season.

Building 11 (heating season)

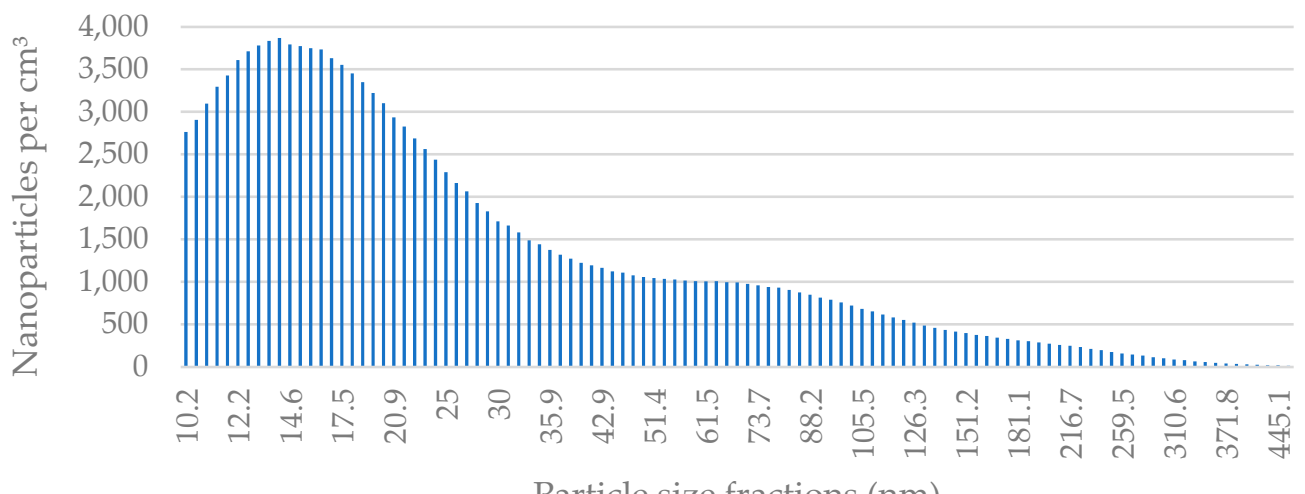

Particle size fractions $(\mathrm{nm})$

Figure A21. The average nanoparticle concentration in each size fraction in Building 11 during a one-week measurement period during the heating season.

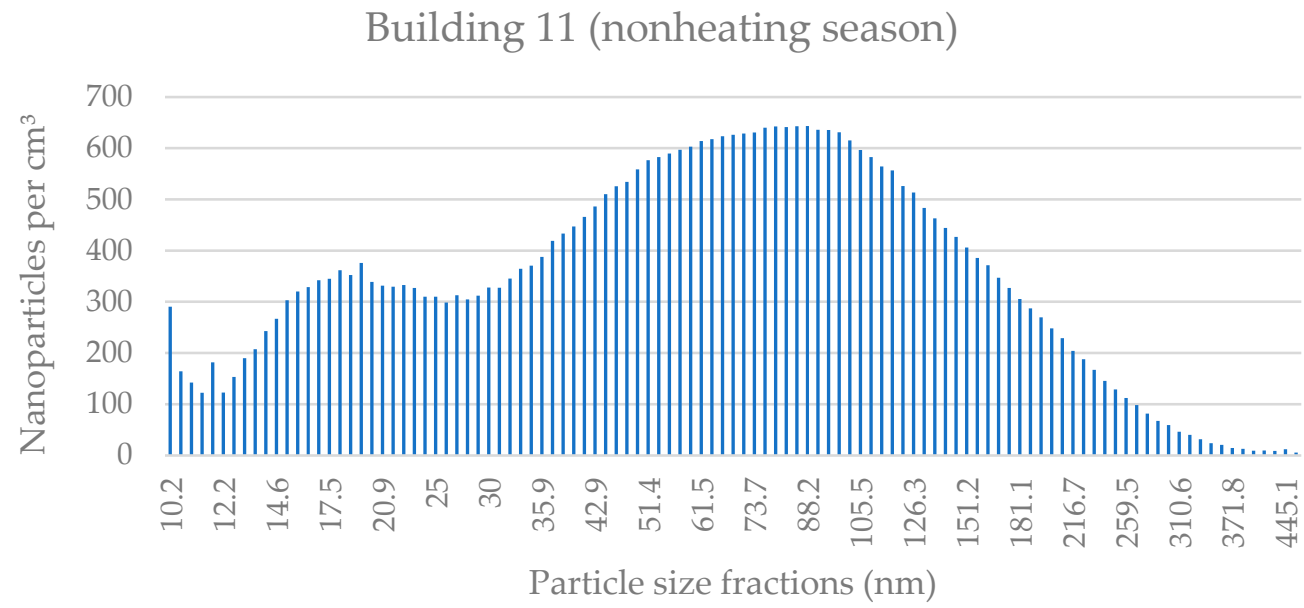

Figure A22. The average nanoparticle concentration in each size fraction in Building 11 during a one-week measurement period during the nonheating season. 


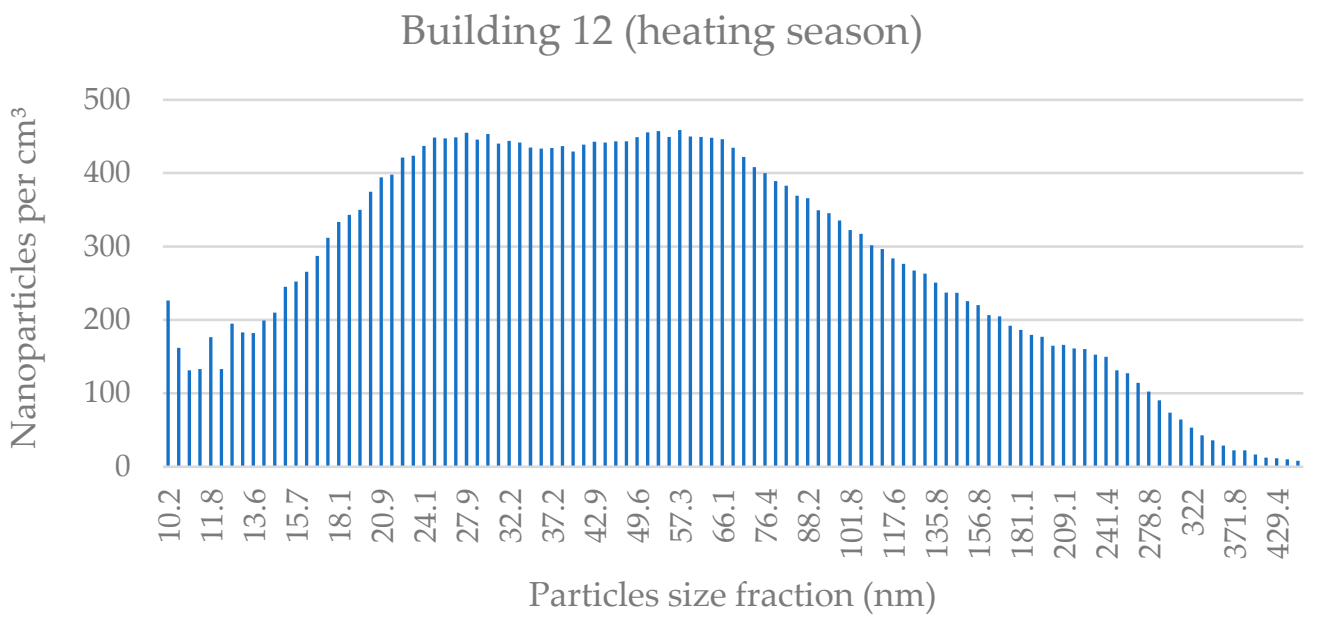

Figure A23. The average nanoparticle concentration in each size fraction in Building 12 during a one-week measurement period during the heating season.

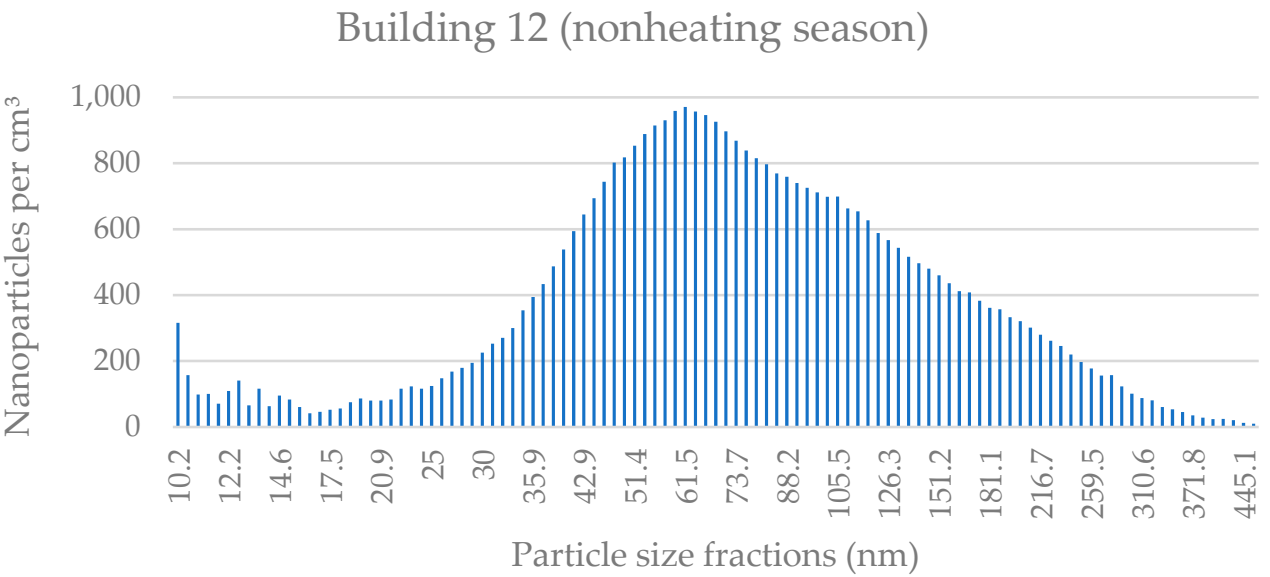

Figure A24. The average nanoparticle concentration in each size fraction in Building 12 during a one-week measurement period during the nonheating season.

\section{References}

1. Barua, S.; Mitragotri, S. Challenges associated with penetration of nanoparticles across cell and tissue barriers: A review of current status and future prospects. Nano Today 2014, 9, 223-243. [CrossRef] [PubMed]

2. Laurent, S.; Forge, D.; Port, M.; Roch, A.; Robic, C.; Vander Elst, L.; Muller, R.N. Magnetic iron oxide nanoparticles: Synthesis, stabilization, vectorization, physicochemical characterizations, and biological applications. Chem. Rev. 2008, 108, $2064-2110$. [CrossRef] [PubMed]

3. European Commission. Commission recommendation of 18 October 2011 on the definition of nanomaterial. Off. J. Eur. Union 2011, 275, 38 .

4. Höck, J.; Epprecht, T.; Furrer, E.; Gautschi, M.; Hofmann, H.; Höhener, K.; Knauer, K.; Krug, H.; Limbach, L.; Gehr, P. Guidelines on the Precautionary Matrix for Synthetic Nanomaterials; Federal Office for Public Health and Federal Office for the Environment: Bern, Switzerland, 2010.

5. Wallace, L.A.; Ott, W.R.; Weschler, C.J. Ultrafine particles from electric appliances and cooking pans: Experiments suggesting desorption/nucleation of sorbed organics as the primary source. Indoor Air 2015, 25, 536-546. [CrossRef]

6. Mohajerani, A.; Burnett, L.; Smith, J.V.; Kurmus, H.; Milas, J.; Arulrajah, A.; Horpibulsuk, S.; Abdul Kadir, A. Nanoparticles in construction materials and other applications, and implications of nanoparticle use. Materials 2019, 12, 3052. [CrossRef]

7. Shi, X.; Chen, R.; Huo, L.; Zhao, L.; Bai, R.; Long, D.; Pui, D.Y.; Rang, W.; Chen, C. Evaluation of nanoparticles emitted from printers in a clean chamber, a copy center and office rooms: Health risks of indoor air quality. J. Nanosci. Nanotechnol. 2015, 15, 9554-9564. [CrossRef] 
8. Morawska, L.; Ayoko, G.A.; Bae, G.N.; Buonanno, G.; Chao, C.Y.H.; Clifford, S.; Fu, S.C.; Hänninen, O.; He, C.; Isaxon, C.; et al. Airborne particles in indoor environment of homes, schools, offices and aged care facilities: The main routes of exposure. Environ. Int. 2017, 108, 75-83. [CrossRef]

9. Tran, V.V.; Park, D.; Lee, Y.-C. Indoor air pollution, related human diseases, and recent trends in the control and improvement of indoor air quality. Int. J. Environ. Res. Public Health 2020, 17, 2927. [CrossRef]

10. Atkinson, J.; Chartier, Y.; Otaiza, F.; Pessoa-Silva, C.L. Concepts and types of ventilation. In Natural Ventilation for Infection Control in Health-Care Settings; Atkinson, J., Chartier, Y., Pessoa-Silva, C.L., Jensen, P., Li, Y., Seto, W.H., Eds.; World Health Organization: Geneva, Switzerland, 2009; pp. 7-15.

11. Irga, P.J.; Torpy, F.R. Indoor air pollutants in occupational buildings in a sub-tropical climate: Comparison among ventilation types. Build. Environ. 2016, 98, 190-199. [CrossRef]

12. Park, J.S.; Jee, N.Y.; Jeong, J.W. Effects of types of ventilation system on indoor particle concentrations in residential buildings. Indoor Air 2014, 24, 629-638. [CrossRef]

13. Jamriska, M.; Morawska, L.; Ensor, D.S. Control strategies for sub-micrometer particles indoors: Model study of air filtration and ventilation. Indoor Air 2003, 13, 96-105. [CrossRef]

14. Thornburg, J.; Ensor, D.S.; Rodes, C.E.; Lawless, P.A.; Sparks, L.E.; Mosley, R.B. Penetration of particles into buildings and associated physical factors. Part I: Model development and computer simulations. Aerosol Sci. Technol. 2001, 34, 284-296. [CrossRef]

15. Karjalainen, P.; Saari, S.; Kuuluvainen, H.; Kalliohaka, T.; Taipale, A.; Rönkkö, T. Performance of ventilation filtration technologies on characteristic traffic related aerosol down to nanocluster size. Aerosol Sci. Technol. 2017, 51, 1398-1408. [CrossRef]

16. Ekberg, L. Ventilationsfilters Betydelse för Inomhusluftens Innehåll av Partiklar; CIT Energy Management AB, Camfil Svenska AB: Göteborg, Sweden, 2016.

17. Cyrys, J.; Pitz, M.; Bischof, W.; Wichmann, H.E.; Heinrich, J. Relationship between indoor and outdoor levels of fine particle mass, particle number concentrations and black smoke under different ventilation conditions. J. Expo. Anal. Environ. Epidemiol. 2004, 14, 275-283. [CrossRef]

18. Lv, Y.; Wang, H.; Wei, S.; Zhang, L.; Zhao, Q. The correlation between indoor and outdoor particulate matter of different building types in Daqing, China. Procedia Eng. 2017, 205, 360-367. [CrossRef]

19. Miller, S.L.; Facciola, N.A.; Toohey, D.; Zhai, J. Ultrafine and fine particulate matter inside and outside of mechanically ventilated buildings. Int. J. Environ. Res. Public Health 2017, 14, 128. [CrossRef] [PubMed]

20. Koponen, I.; Asmi, A.; Keronen, P.; Puhto, K.; Kulmala, M. Indoor air measurement campaign in Helsinki, Finland 1999—The effect of outdoor air pollution on indoor air. Atmos. Environ. 2001, 35, 1465-1477. [CrossRef]

21. Hussein, T.; Hämeri, K.; Aalto, P.; Asmi, A.; Kakko, L.; Kulmala, M. Particle size characterization and the indoor-to-outdoor relationship of atmospheric aerosols in Helsinki. Scand. J. Work. Environ. Health 2004, 30 (Suppl. 2), 54-62. [PubMed]

22. Zhu, Y.; Hinds, W.C.; Krudysz, M.; Kuhn, T.; Froines, J.; Sioutas, C. Penetration of freeway ultrafine particles into indoor environments. J. Aerosol Sci. 2005, 36, 303-322. [CrossRef]

23. Wang, Y.; Hopke, P.K.; Chalupa, D.C.; Utell, M.J. Long-term characterization of indoor and outdoor ultrafine particles at a commercial building. Environ. Sci. Technol. 2010, 44, 5775-5780. [CrossRef] [PubMed]

24. Orru, H.; Hagenbjörk, A.; Olstrup, H. Indoor and outdoor nanoparticle concentrations in an urban background area in northern Sweden: The NanoOffice study. Environments 2021, 8, 75. [CrossRef]

25. Stasiulaitiene, I.; Krugly, E.; Prasauskas, T.; Ciuzas, D.; Kliucininkas, L.; Kauneliene, V.; Martuzevicius, D. Infiltration of outdoor combustion-generated pollutants to indoors due to various ventilation regimes: A case of a single-family energy efficient building. Build. Environ. 2019, 157, 235-241. [CrossRef]

26. Isaxon, C.; Gudmundsson, A.; Nordin, E.Z.; Lönnblad, L.; Dahl, A.; Wieslander, G.; Bohgard, M.; Wierzbicka, A. Contribution of indoor-generated particles to residential exposure. Atmos. Environ. 2015, 106, 458-466. [CrossRef]

27. Kim, K.-H.; Kabir, E.; Jahan, S.A. Airborne bioaerosols and their impact on human health. J. Environ. Sci. 2018, 67, 23-35. [CrossRef] [PubMed]

28. Kwon, H.S.; Ryu, M.H.; Carlsten, C. Ultrafine particles: Unique physicochemical properties relevant to health and disease. Exp. Mol. Med. 2020, 52, 318-328. [CrossRef] [PubMed]

29. Guyot, G.; Sherman, M.; Walker, I.; Clark, J. Residential Smart Ventilation: A Review; Report Number: 201056; Lawrence Berkeley National Laboratory: Berkeley, CA, USA, 2017.

30. Shi, B. Removal of Ultrafine Particles by Intermediate Air Filters in Ventilation Systems: Evaluation of Performance and Analysis of Applications; Chalmers Tekniska Hogskola: Göteborg, Sweden, 2012.

31. Fazli, T.; Zeng, Y.; Stephens, B. Fine and ultrafine particle removal efficiency of new residential HVAC filters. Indoor Air 2019, 29, 656-669. [CrossRef]

32. Singer, B.C.; Delp, W.W.; Black, D.R.; Walker, I.S. Measured performance of filtration and ventilation systems for fine and ultrafine particles and ozone in an unoccupied modern California house. Indoor Air 2017, 27, 780-790. [CrossRef]

33. Stephens, B.; Siegel, J.A. Ultrafine particle removal by residential heating, ventilating, and air-conditioning filters. Indoor Air 2013, 23, 488-497. [CrossRef]

34. van der Zee, S.C.; Strak, M.; Dijkema, M.B.A.; Brunekreef, B.; Janssen, N.A.H. The impact of particle filtration on indoor air quality in a classroom near a highway. Indoor Air 2017, 27, 291-302. [CrossRef] 
35. Sultan, Z.M.; Nilsson, G.J.; Magee, R.J. Removal of ultrafine particles in indoor air: Performance of various portable air cleaner technologies. HvacER Res. 2011, 17, 513-525. [CrossRef]

36. Eurovent. Energy Efficiency Evaluation of Air Filters for General Ventilation Purposes; Eurovent: Brussels, Belgium, 2019.

37. Rojas, G. Particle filtration in energy efficient housing with MVHR. Rehva J. 2020, 57, 8-11.

38. Waring, M.S.; Ben-David, T.; Wang, S. Impact of High-Efficiency Filtration Combined with High Ventilation Rates on Particulate Matter Concentrations in US Offices. In Proceedings of the NAFA Annual Convention 2017, Annapolis, MD, USA, 20-22 September 2017. 